\title{
Preference and User Experience with Powered Air- purifying Respirators in Healthcare Workers in a Simulated Work Environment: A Pilot Study
}

\author{
Lauren MacDowell
}

Follow this and additional works at: https://researchrepository.wvu.edu/etd

\author{
Recommended Citation \\ MacDowell, Lauren, "Preference and User Experience with Powered Air- purifying Respirators in \\ Healthcare Workers in a Simulated Work Environment: A Pilot Study" (2018). Graduate Theses, \\ Dissertations, and Problem Reports. 6130. \\ https://researchrepository.wvu.edu/etd/6130
}

This Thesis is protected by copyright and/or related rights. It has been brought to you by the The Research Repository @ WVU with permission from the rights-holder(s). You are free to use this Thesis in any way that is permitted by the copyright and related rights legislation that applies to your use. For other uses you must obtain permission from the rights-holder(s) directly, unless additional rights are indicated by a Creative Commons license in the record and/ or on the work itself. This Thesis has been accepted for inclusion in WVU Graduate Theses, Dissertations, and Problem Reports collection by an authorized administrator of The Research Repository @ WVU. For more information, please contact researchrepository@mail.wvu.edu. 


\title{
Preference and User Experience with Powered Air- Purifying Respirators in Healthcare Workers in a Simulated Work Environment: A Pilot Study
}

\section{Lauren MacDowell}

Thesis submitted to the Statler College of Engineering and Mineral Resources at West Virginia University

in partial fulfillment of the requirements for the degree of

\author{
Master of Science \\ in \\ Industrial Hygiene \\ Xinjian He, Ph.D., Chair \\ Steven Guffey, Ph.D. \\ Anna Allen, MD. \\ Department of Industrial and Management Systems Engineering
}

Morgantown, West Virginia

2018

Keywords: Healthcare workers, PAPRs, user comfort, acceptability, perceived protections, user experience

Copyright 2018: Lauren MacDowell 


\section{Abstract \\ Preference and User Experience with Powered Air-Purifying Respirators in Healthcare Workers in a Simulated Work Environment: A Pilot Study}

\section{Lauren MacDowell}

Powered air-purifying respirators (PAPRs) are protective devices commonly utilized by healthcare workers in environments with infectious airborne diseases. A review of the current PAPR literature indicated a shortage of studies that focus on user experience of PAPRs and the types of PAPRs that healthcare workers prefer. This study focused on three different PAPR models: the MAXAIR CAPR® 710, the $3 \mathrm{M}^{\mathrm{TM}}$ Versaflo ${ }^{\mathrm{TM}} \mathrm{TR}-600-\mathrm{ECK}$ and the $3 \mathrm{M}^{\mathrm{TM}}$ AirMate $^{\mathrm{TM}}$. A typical hospital patient work environment was simulated at the West Virginia Simulation Training and Education for Patient Safety on West Virginia University's Health Sciences Campus. Eight subjects total were recruited and asked to perform various tasks in the simulated patient room while wearing the different respirators. Data was collected via a survey which compiled information on 16 different evaluation categories, vitals and preferences and acceptability of the different PAPRs under various risk and air flow conditions. Results yielded 5 statistically significant evaluation categories $(\mathrm{p}<0.05)$ which were "general comfort", "overall breathing discomfort", "clear line of vision", "mechanical interference with duties" and "the number of hours a subject was willing to wear the PAPR". In these 5 categories, the MAXAIR typically performed the best and the Versaflo typically performed the worst. The results indicate a large gap between the MAXAIR and the Versaflo. The MAXAIR was perceived as generally more comfortable, less cumbersome and more effective than the Versaflo. This may indicate an issue in design in the Versaflo, which could be further analyzed with additional studies. 


\section{Acknowledgements}

The author wishes to acknowledge Dr. Xinjian “Kevin” He, Dr. Steven Guffey, Dr. Anna Allen, Huihui Yang and Dan Summers, Adam Hoffman and others from the WVU STEPS center for their help in creating and writing this thesis. 


\section{Table of Contents}

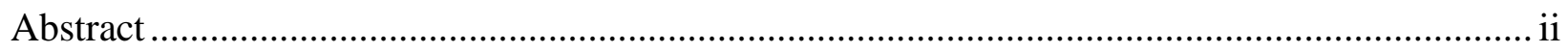

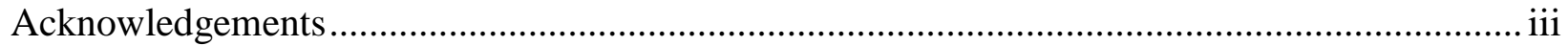

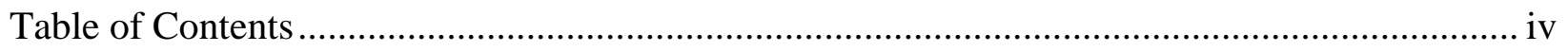

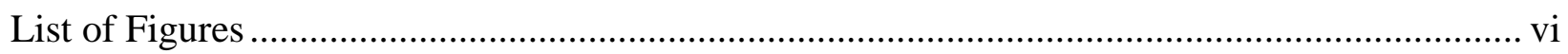

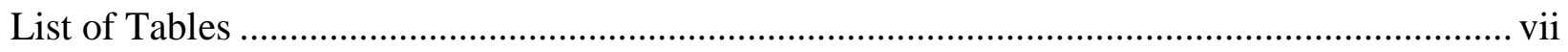

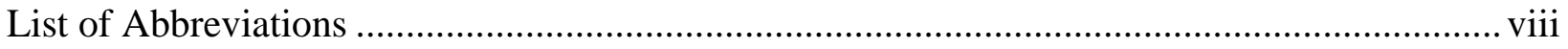

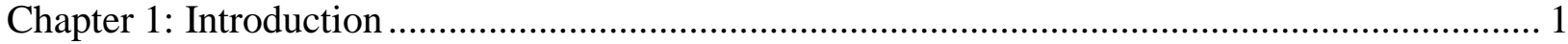

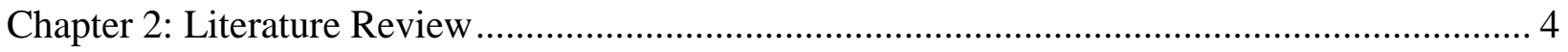

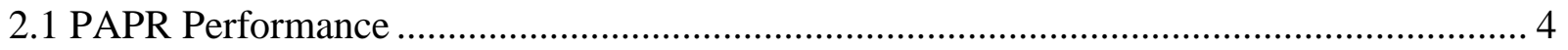

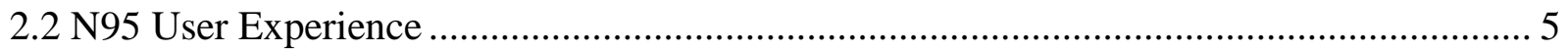

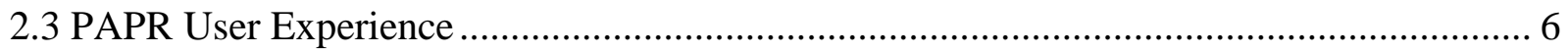

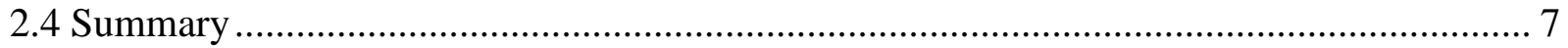

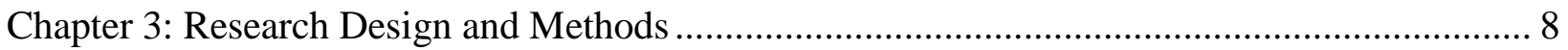

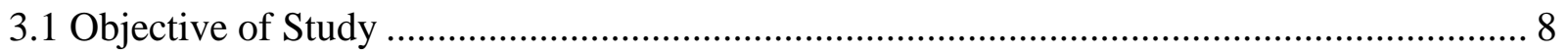

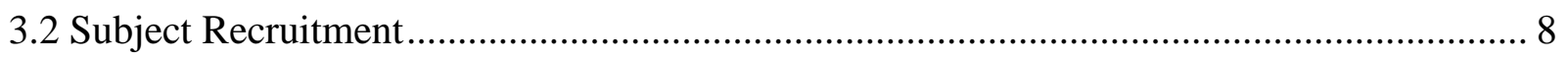

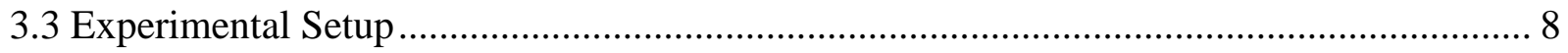

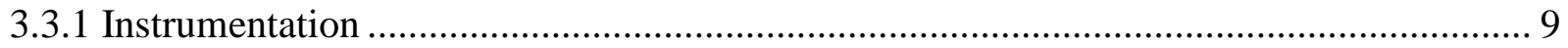

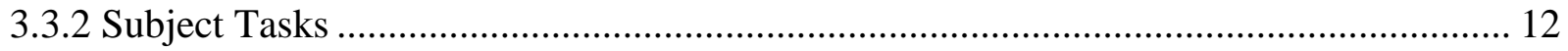

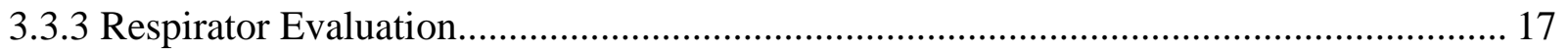

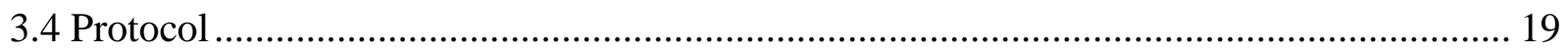

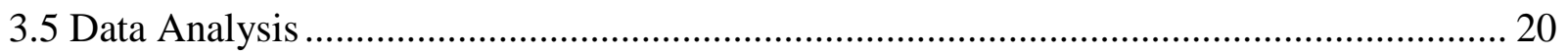

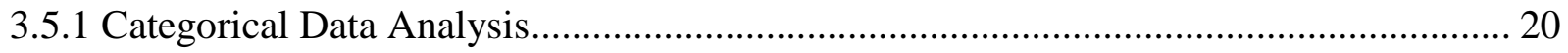

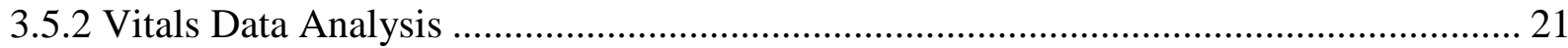

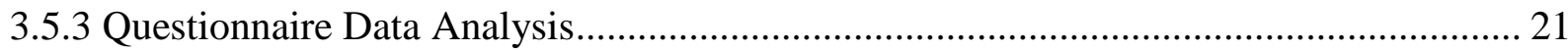

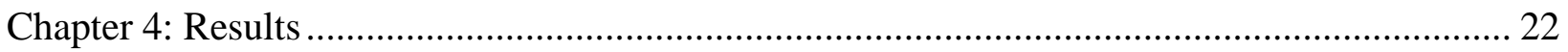

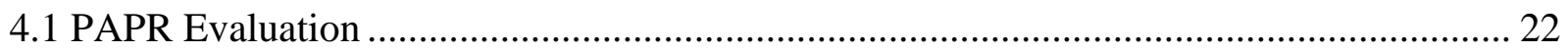

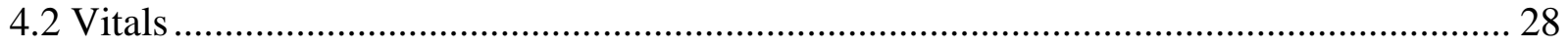

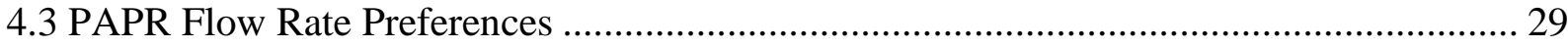

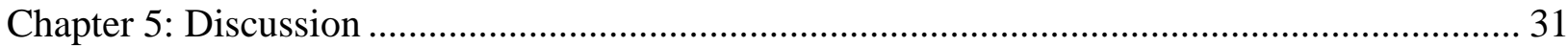

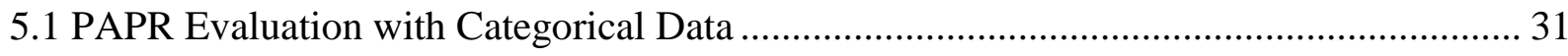


5.2 Vitals

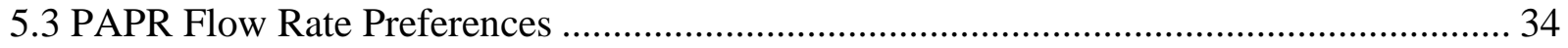

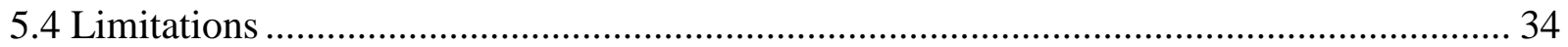

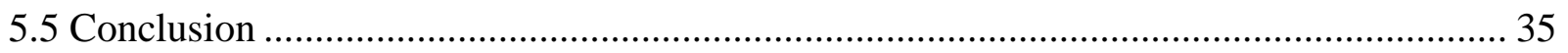

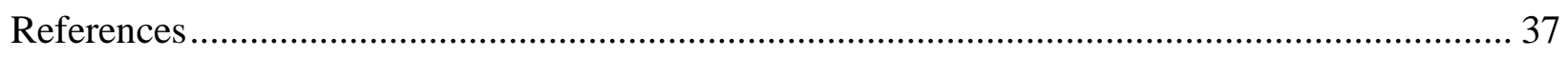

Appendix A: Screening Questionnaire Sample ............................................................ 41

Appendix B: PAPR Questionnaire Sample..................................................................... 42

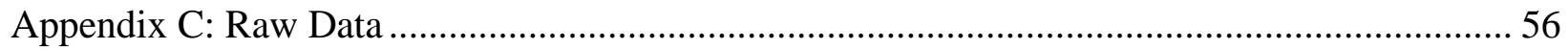

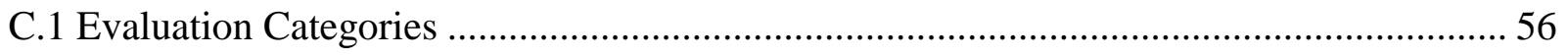

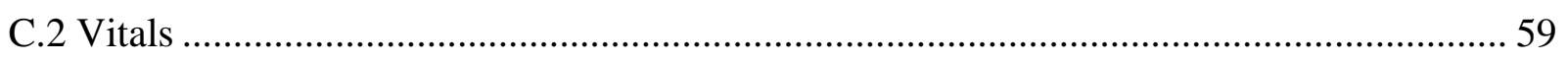

C.2 Preferences and Acceptability Survey Results ......................................................... 61 


\section{List of Figures}

Figure 1: Example of a full face PAPR (source: Airgas) .................................................. 2

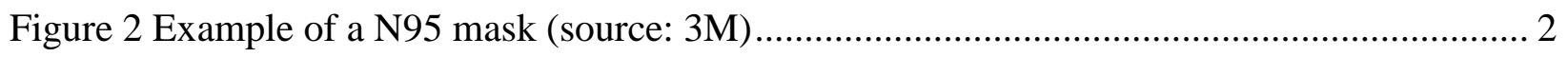

Figure 3 Simulation Room Setup.................................................................................... 9

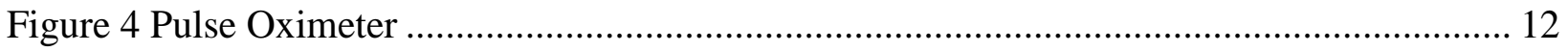




\section{List of Tables}

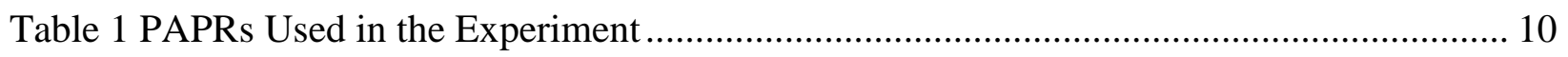

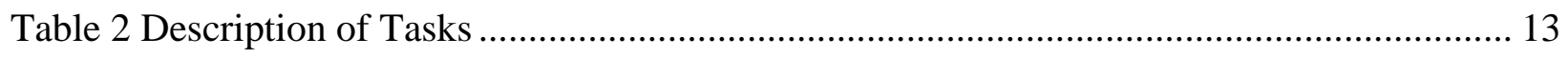

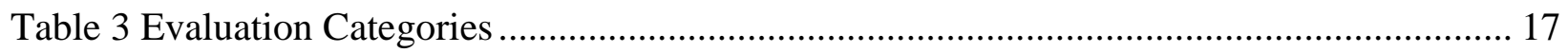

Table 4 Preference and Acceptability Questions ........................................................... 19

Table 5 MAXAIR PAPR Descriptive Results ............................................................... 22

Table 6 Air-Mate PAPR Descriptive Results ................................................................. 23

Table 7 Versaflo PAPR Descriptive Results ................................................................... 23

Table 8 Kruskall-Wallis Test Results for Categorical Data................................................ 25

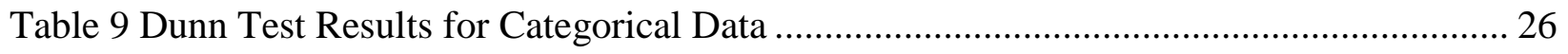

Table 10 MAXAIR Vitals Paired Two Sample T-Test Results............................................ 28

Table 11 Air-Mate Vitals Paired Two Sample T-Test Results ............................................. 28

Table 12 Versiflo Vitals Paired Two Sample T-Test Results............................................... 29

Table 13 Comparing High Flow Rate to Low Flow Rate Preferences and Acceptability Results 29 


\section{List of Abbreviations}

APF

CA

$\mathrm{CDC}$

CPR

DOP

E-RCP

FFR

HCW

HR

HSC

IRB

IV

$\mathrm{NIOSH}$

OSHA

PAPR

RN

RR

SAR

$\mathrm{SpO} 2$

SWPF

WPF

WV STEPS

WVU
Assigned protection factor

Clinical associate

Center for Disease Control

Cardiopulmonary resuscitation

Dioctyl phthalate

Enhanced respiratory and contact precautions

Filtering facepiece respirators

Healthcare worker

Heart rate

Health Sciences Center

Institutional Review Board

Intravenous

The National Institute of Occupational Safety and Health

Occupational Safety and Health Administration

Powered air-purifying respirator

Registered nurse

Respiratory rate

Supplied air respirator

Blood oxygen level

Simulated workplace protection factor

Workplace protection factor

West Virginia Simulation Training and Education for Patient Safety

West Virginia University 


\section{Chapter 1: Introduction}

According to OSHA's Hospital Respiratory Protection Program Toolkit for Respirator Program Administrators, a powered air-purifying respirator, or PAPR, is one of the most common types of respirators in the healthcare field. PAPRs are typically utilized for aerosol generating procedures and are worn most often by hospital first receivers or by those who are unable to wear a tight-fitting respirator (OSHA, 2015). PAPRs are able to protect the worker from a variety of different hazards encountered in the healthcare field including biological agents, toxic vapors and solvents (special chemical cartridges or canisters are required for gas/vapor contaminants) (OSHA, 2005). In addition, OSHA recommends the use of PAPRs "when the hazardous substance is unknown and unquantified" (OSHA, 2005).

The OSHA 1910.134 Respiratory Protection standard defines a PAPR as "an airpurifying respirator that uses a blower to force the ambient air through air-purifying elements to the inlet covering" (OSHA, 2015). This battery powered blower creates a positive pressure inside the facepiece or hood in order to keep airborne contaminants from entering the respirator. An example of a PAPR is shown in Figure 1. Filters are used when protecting the worker from particles and cartridges are used for gases and vapors. PAPRs may be worn as a half mask, a fullface piece, a helmet, a hood, or as a loose-fitting face piece. The loose-fitting PAPRs do not require fit testing (OSHA, 2015). The National Institute of Occupational Safety and Health (NIOSH) is the agency responsible for developing standards and test procedures for PAPRs (CDC, 2003). 


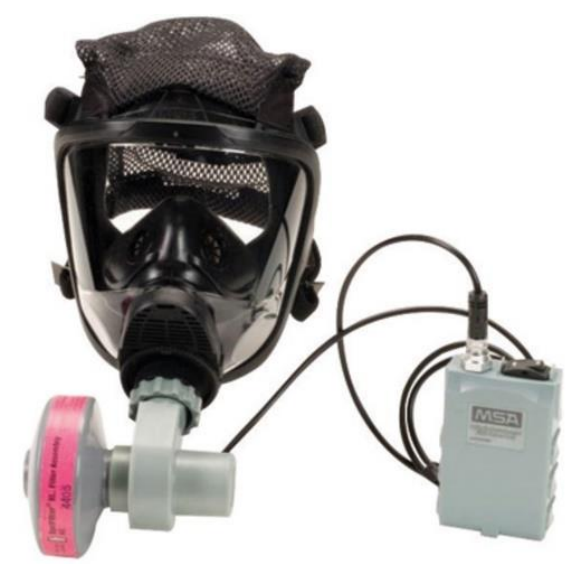

Figure 1: Example of a full face PAPR (source: Airgas)

According to the OSHA Hospital Respiratory Protection Program Toolkit, PAPRs "are generally more protective than non-powered half mask respirators because the blower creates positive pressure inside the facepiece, reducing inward leakage of potentially contaminated air." PAPRs are also more effective in high work rate situations as the powered air removes any breathing resistance issues (Occupational Health \& Safety, 1996). However, PAPRs are significantly heavier and frequently more expensive than standard air purifying respirators (APRs). The much lighter and relatively inexpensive N95 face mask is also utilized often in healthcare settings to protect against airborne particles (Food \& Drug Administration). The N95 label of these masks indicate that they are able to block "at least $95 \%$ of very small ( 0.3 micron) test particles" (Food \& Drug Administration). An example of an N95 mask is shown in Figure 2. However, as previously stated, these masks are not as protective as PAPRs [ref].

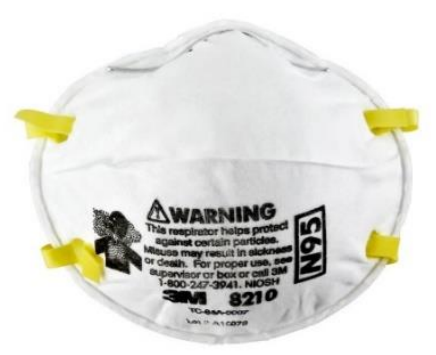

Figure 2 Example of a N95 mask (source: 3M)

As mentioned previously, PAPRs are widely used by hospital "first receivers" who are the first on site for a medical emergency. In these situations, the hazards are typically unknown. 
Because the PAPR is considered to be much more protective than other respiratory protective equipment, they are recommended and used frequently. In fact, PAPRs were commonly worn during the 2014 West Africa Ebola outbreak (OSHA, 2014). Despite the many advantages of PAPRs, there are a few disadvantages as well. In a Tuberculosis Respiratory Protection Guide in Health Care Facilities Administrator's Guide produced by the Center for Disease Control (CDC), several disadvantages of PAPRs are listed. These disadvantages include the inability to use a PAPR in a sterile field, the batteries for the blower must be recharged, frequent maintenance, possible communication issues and PAPRs can be heavy and noisy. These disadvantages could possibly steer healthcare workers (HCWs) away from using PAPRs in their workplaces. Currently, there is insufficient information regarding HCW user experience and the perceived efficiency of PAPRs.

The purpose of this study was to discuss results obtained from a pilot study using eight HCW subjects. This study evaluated discomfort, acceptability and perceived protection of three PAPR respirators. These results may help PAPR manufacturers understand the possible issues and shortcomings of the respirator design and make adjustments in order to improve the respiratory protection for the HCWs in the field. 


\section{Chapter 2: Literature Review}

\subsection{PAPR Performance}

According to the OSHA 1910.134 Respiratory Protection Standard, the performance of a PAPR is denoted by its assigned protection factor (APF). These numbers indicate the workplace level of respiratory protection. For PAPRs, these factors are listed as 50 for half-mask, 1,000 for full facepiece, 25 for helmet, 1,000 for hood, and 25 for loose fitting facepiece (OSHA, 2015). These numbers are used to select PAPRs in the workplace and are determined using quantitative fit factors. However, these APFs may not translate accurately into the workplace. One study found that the two PAPRs tested produced a workplace protection factor (WPF) less than the APF of 1,000 (Myers et al, 1984). The study found no correlation between quantitative fit factors and workplace protection factors. Due to some of the controversy regarding APFs, some individuals in the respirator standard community, manufacturers and industrial sectors have focused on both the WPF and the simulated workplace protection factor (SWPF) (Martin et al, 2006).

Other studies have investigated PAPR performance and protection in different ways. In a study evaluating supplied air respirators (SARs) and PAPRs, Cohen et al (2001) measured SWPFs. PAPRs were found to have a higher minimum protection factor when compared to SARs. However, some believe that these SWPF and WPF studies have a "level of disagreement" and "fail to address the issue of total PAPR unit performance over extended time" (Martin et al, 2006). Martin et al performed a specific 8-hour test using a dioctyl phthalate (DOP) loading test on 5 PAPRs, of which two were loose-fitting, two were tight-fitting and one used an electrostatic filter. Martin et al found that for the loose-fitting PAPRs, the performance test without the breathing machine proved more rigorous but the results were inconclusive for the tight-fitting PAPR. The results also showed that a PAPR with an electrostatic filter produced the highest penetration values (Martin et al, 2006). Their results show that PAPR unit performance and the use of an electrostatic filter are both areas of concern in PAPR use.

PAPRs can also be potentially evaluated with advanced manikin headforms. This is a

method designed by NIOSH for evaluating filtering facepiece respirator fit but has recently shown some potential for use in evaluating PAPR performance (Bergman et al, 2017). 
Performance wise, PAPRs have been shown to decrease the risk of contaminant of healthcare workers when compared to donning enhanced respiratory and employing contact precautions or E-RCP (Zamora et al, 2006). E-RCP systems can lead to contamination on the arms and hands while the PAPR-based protection system has a much lower risk for contamination of the HCW. Loose-fitting PAPRs have also demonstrated good protection against nanoparticle exposures (Koivisto et al, 2015). However, a PAPR-based protection system can require "more time to don and remove it. Despite coaching by another person, a significantly higher number of participants committed violations while donning the PAPR system" (Zamora et al, 2006). These donning violations can cause other risks to occur for the HCW. The donning of the PAPR has been shown to affect respirator fit significantly more than a typical fit test protocol (Crutchfield et al, 1999). Furthermore, PAPRs can also be either improperly sized or can become easily stretched out from use. When this occurs, the PAPR provides significantly less protection (Gao, 2016). Administrators should supply HCWs with properly sized equipment and remove any stretched out PAPRs to better ensure their employees' health and safety.

\subsection{N95 User Experience}

N95 masks are commonly used throughout the healthcare environment. However, during their use throughout the day, the mask may produce perceived or measurable physiological effects on HCWs. Considering N95 masks with and without exhalation valves, only mild physiological effects were observed during realistically low rates of work (Roberge et al, 2010). However, workers reported that masks with exhalation valves were more comfortable (Roberge et al, 2010). This agrees with a study by Radonovich et al in 2009 which investigated respirator tolerance by HCWs. In their study, N95 masks with exhalation valves were better tolerated as well. However, participants were unwilling to wear the masks for the entire 8-hour work shift, citing pressure, facial heat and communication interference (Radonovich et al, 2009). Respirator tolerance appears to be most influenced by perceived discomfort of the $\mathrm{HCW}$, and not their overall physical exertion during the 8-hour shift (Shenal et al, 2012). N95 masks have not been shown to have any major pulmonary or heart rate impact during use (Kim et al, 2013).

Perceived discomfort of N95 masks is relatively well studied. It is an important subject to study as the perceived discomfort of the masks may interfere with occupational duties (Shenal et al, 2012). Facial heat is one of the leading causes of respirator intolerance (Radonovich et al, 
2009). Wearing an N95 mask does not appear to pose a significant increase in thermal burden on the body's core temperature, but instead significantly increases the temperature of the covered facial skin of a worker (Roberge et al, 2012). This can lead to the individual perceiving that the core body temperature is increasing. In measuring the deadspace created by the N95 mask, Roberge et al observed that after an hour of use, the humidity and temperature increased in the deadspace. Furthermore, N95 masks with exhalation valves had much less temperature increase in the deadspace (Roberge et al, 2012). The humidity build up within the mask also produced moisture on the mask surface. Despite this moisture build up, there has been no evidence of major breathing resistance occurring as a result (Roberge et al, 2010). Lastly, when compared to a higher filtering P100 mask, an N95 mask could not retain its fit as well in a hot, humid workplace (Kim et al, 2016).

N95 masks have been observed to cause other forms of discomfort and inconvenience to HCWs. In one study by Lim et al in 2006, a survey was distributed to $212 \mathrm{HCWs}$ to determine if headaches were associated with N95 mask use. Of the 79 who responded, 32.9\% reported headache frequency exceeding six times per month. Furthermore, 59.5\% of respondents reported taking medications to treat their headaches (Lim et al, 2006). An association was found between headaches and continuous use of the N95 mask exceeding 4 hours. N95 masks can also cause issues with communication in the workplace as well. In one study, the N95 mask was observed to have the largest impact on speech intelligibly interference when compared to regular protective facemasks and elastomeric air-purifying respirators (Palmiero et al, 2016). This may be due to the mask's thickness and adherence to the face.

\subsection{PAPR User Experience}

PAPRs have also been observed in some studies to be inconvenient or cause discomfort. PAPRs are battery powered and thus the charge of the battery on the pump has an effect on its performance and flow rates. As the flow rate decreases, the user must expend more effort to breathe (Johnson et al, 2005). Thermal comfort and breathing apparatus comfort can decrease as the flow rate decreases as well. Battery charge is important for maintaining the comfort and protection levels of the PAPR. While in most instances, a full or mostly charged battery is possible, "during emergencies when times of physical activity may be lengthened significantly, 
respiratory flow rates are higher than normal, and the luxury of battery recharge cannot be availed, then a $20 \%$ reduction in performance capability could be critical” (Johnson et al, 2005).

Thermal comfort of the face is much less of an issue with PAPRs as compared to N95 masks due to the battery powered flow of air. However, physical exertion while wearing an elastomeric PAPR can cause an increase in forehead skin temperature, leading to an overall perception of body core thermal discomfort (Powell et al, 2017). The flow of air also can cause an additional perception of discomfort. In the tight-fitting full facepiece PAPR, subjects reported a perception of eye dryness (Powell et al, 2017).

PAPRs, due to their nature, can also have a negative effect on speech intelligibility as well. In one study, hearing clarity was found to be $79 \%$ as opposed to $90 \%$ clarity without the use of a PAPR (Radonovich, 2010). A study by Khoo et al also confirmed this with similar results. In their study, HCWs were surveyed on their perceptions of the PAPR. Many reported having to raise their voice in order to communicate properly. Despite some inconveniences, their study also demonstrated the overall acceptance of PAPRs. Most HCWs found their PAPR comfortable and preferred its use over N95 masks when working with patients infected with either SARS or TB.

\subsection{Summary}

The literature has demonstrated that PAPRs can protect well against biological agents, resist contamination well and can even protect the user from nanoparticle exposure. However, PAPRs take significantly more time to don and are commonly improperly worn (Zamora et al, 2006). N95 users have been observed to experience facial thermal discomfort, reduced speech intelligibility and headaches. In the few studies on PAPR user experience, PAPRs can produce issues with speech clarity, forehead thermal discomfort and eye dryness (Johnson et al, 2005; Powell et al, 2017; Radonovich, 2010). Despite this, some studies have discovered that the PAPR is perceived as relatively comfortable and has a low risk of facial thermal discomfort.

While there are many studies on N95 mask user experience, there are very few on PAPR user experience. There appear to be a lack of studies that focus primarily on a healthcare worker's perceived acceptability, comfort and effectiveness of the PAPR. 


\section{Chapter 3: Research Design and Methods}

\subsection{Objective of Study}

The objective of this study is to identify the differences in perceived comfort, acceptability and efficiency between three different PAPRs: the MAXAIR CAPR ${ }^{\circ} 710$, the $3 \mathrm{M}^{\mathrm{TM}}$ Versaflo ${ }^{\mathrm{TM}} \mathrm{TR}-600-\mathrm{ECK}$ and the $3 \mathrm{M}^{\mathrm{TM}}$ Air-Mate ${ }^{\mathrm{TM}}$. Using the results of the study, the three PAPRs can be compared to one another to determine which PAPR the HCW subjects preferred overall while in a simulated environment. The study also examines changes in heart rate $(\mathrm{HR})$, blood oxygen levels $(\mathrm{SpO} 2)$ and respiratory rate $(\mathrm{RR})$ to measure any physical strain that the PAPRs may be causing to the HCW.

\subsection{Subject Recruitment}

This study utilized human subjects and required Institutional Review Board (IRB) approval from the West Virginia University (WVU). The IRB approval number for this study was 1710808326. All eight subjects were recruited from the WVU healthcare system. The only requirement for participation was that the subject was a full-time healthcare worker. Almost all subjects who responded were either a registered nurse (RN) or a clinical associate (CA). Subjects had varying years of experience but typically had been in the healthcare field for over a year.

The subjects who expressed interest were screened with the questionnaire in Appendix A. Subjects was specifically selected for those who have used PAPRs previously and for those who were experienced with the twelve tasks described in the questionnaire. These tasks would be the ones subjects would perform during data collection. The most experienced subjects were then contacted and scheduled for data collection based on their availability. Before data collection, subjects were required to be medically cleared for respirator use.

\subsection{Experimental Setup}

The location of the data collection was the West Virginia Simulation Training and Education for Patient Safety (WV STEPS) center on WVU's campus on the third floor of the Health Sciences Center (HSC) - South. Subjects performed their tasks in simulation rooms typically set up in a manner similar to Figure 3. Simulation rooms contained a Laerdal SimMan® 3G mannequin, a bed, monitoring devices, intravenous (IV) bags and equipment, bedding and various medical evaluation equipment such as stethoscopes, Foley kits, suctioning equipment, 
and needles and syringes for drawing blood. An extra mannequin arm which produced practice blood (water and red food coloring) was also included for the subjects to be able to properly draw blood during the data collection. The rooms were kept at $70^{\circ}$ Fahrenheit.

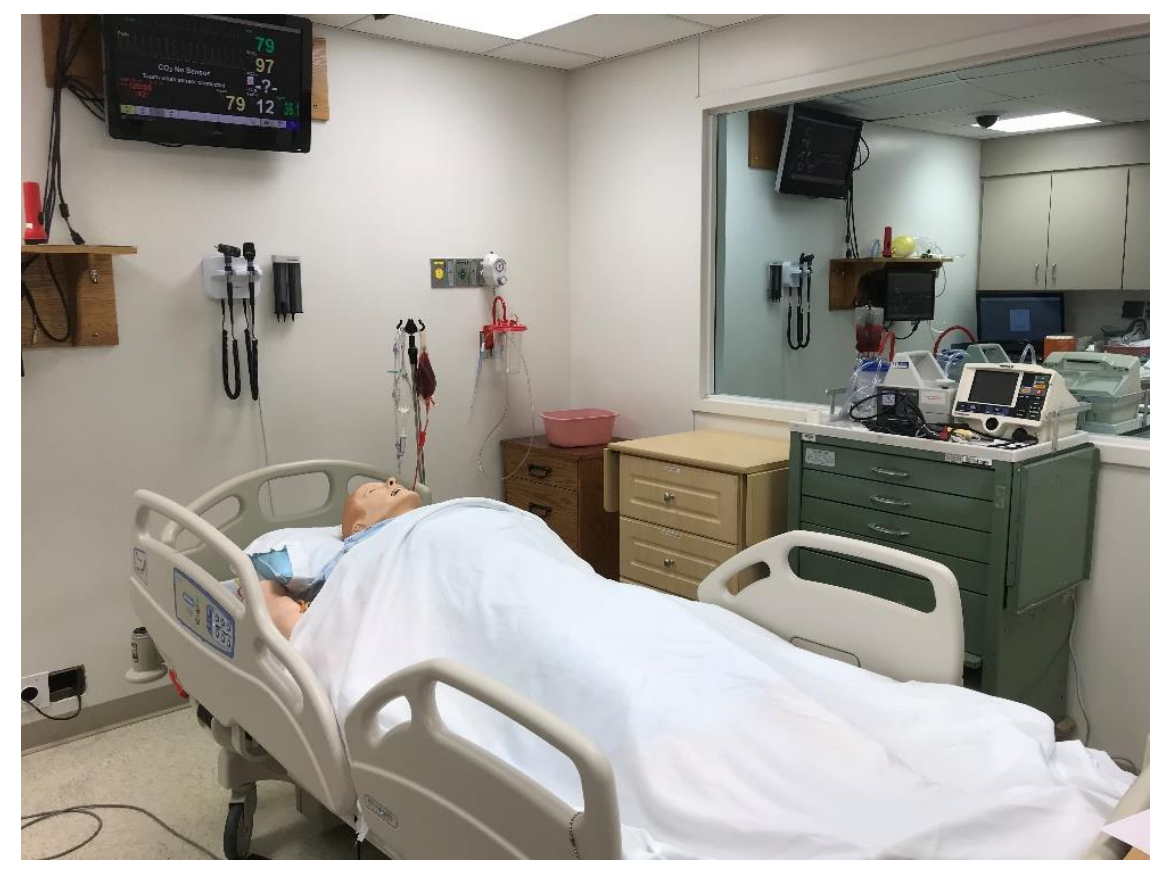

Figure 3 Simulation Room Setup

The mannequin was intended to simulate a real patient. It was controlled via a computer program known as the Laerdal Learning Application in a room next to the simulation lab. This program controlled the mannequin to produce a pulse, breathing and blinking. Pulses could be felt throughout the mannequin body in normal locations such as the neck, wrists and feet. The mannequin also had realistic anatomy, allowing the subjects to properly bathe the mannequin and to insert the Foley catheter to take urine samples. A spring in the mannequin's chest also allowed for more realistic compressions during cardiopulmonary resuscitation (CPR). The mannequin weighed approximately 85 pounds and was 5.9 feet long.

\subsubsection{Instrumentation}

The three PAPRs studied in this investigation are shown in the Table 1. Each PAPR was cleaned thoroughly between uses in order to protect the subjects' health. 
Table 1 PAPRs Used in the Experiment

\begin{tabular}{l}
\multicolumn{1}{|c|}{ PAPR } \\
MAXAIR CAPR ${ }^{\circ} 710$ System \\
DLC-double shroud (loose-fitting) \\
Total Weight: 2.5 pounds \\
\hline 3MTM Versaflo TM TR-600-ECK \\
PAPR (loose-fitting) \\
Total Weight: 4.5 pounds
\end{tabular}




\begin{tabular}{|l|l|}
\hline \multicolumn{1}{|c|}{ PAPR } & Image \\
3igh Efficiency Powered Air \\
Purifying Respirator (PAPR) \\
Total Weight: 3.0 pounds
\end{tabular}

Before and after each task, subject vitals were taken. These included heart rate, blood oxygen levels and respiratory rate. The heart rate and blood oxygen level were measured with a Nellcor OxiMax N-65 pulse oximeter provided by the WV STEPS center (see Figure 4). Respiratory rate was self-measured by the subject. 


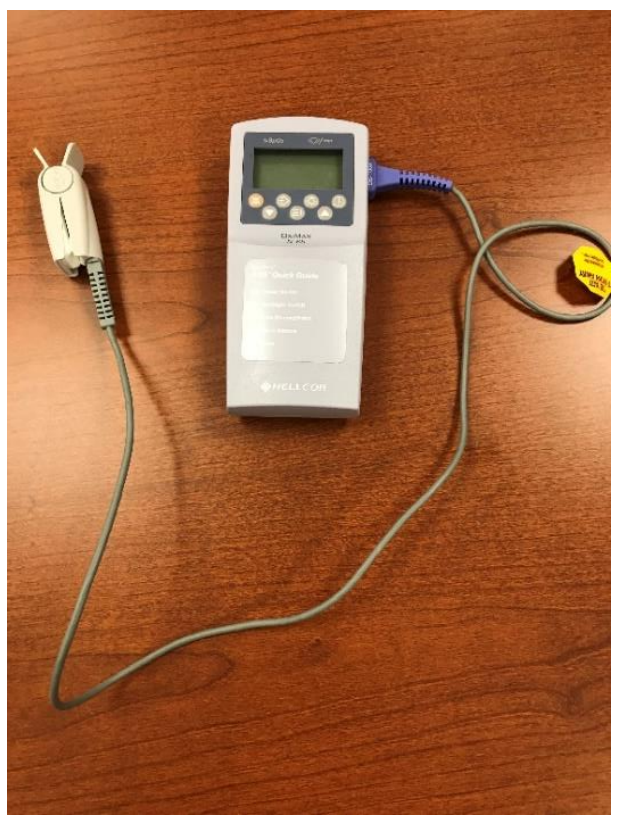

Figure 4 Pulse Oximeter

\subsubsection{Subject Tasks}

Subjects were instructed to perform a set of twelve different tasks for each PAPR they donned. All tasks were performed for each PAPR in turn. These tasks were developed to simulate a regular day in the healthcare field, thus providing a reasonable test to determine if the PAPR hindered any routine activities with a patient. Subjects were asked to perform these tasks for a total of at least 15 minutes in order for them to experience each PAPR fully. Some subjects completed the tasks in exactly 15 minutes and other subjects completed the tasks in 18-20 minutes. However, task completion time was relatively similar for each PAPR. The tasks performed by the subjects are described in Table 2 . 
Table 2 Description of Tasks

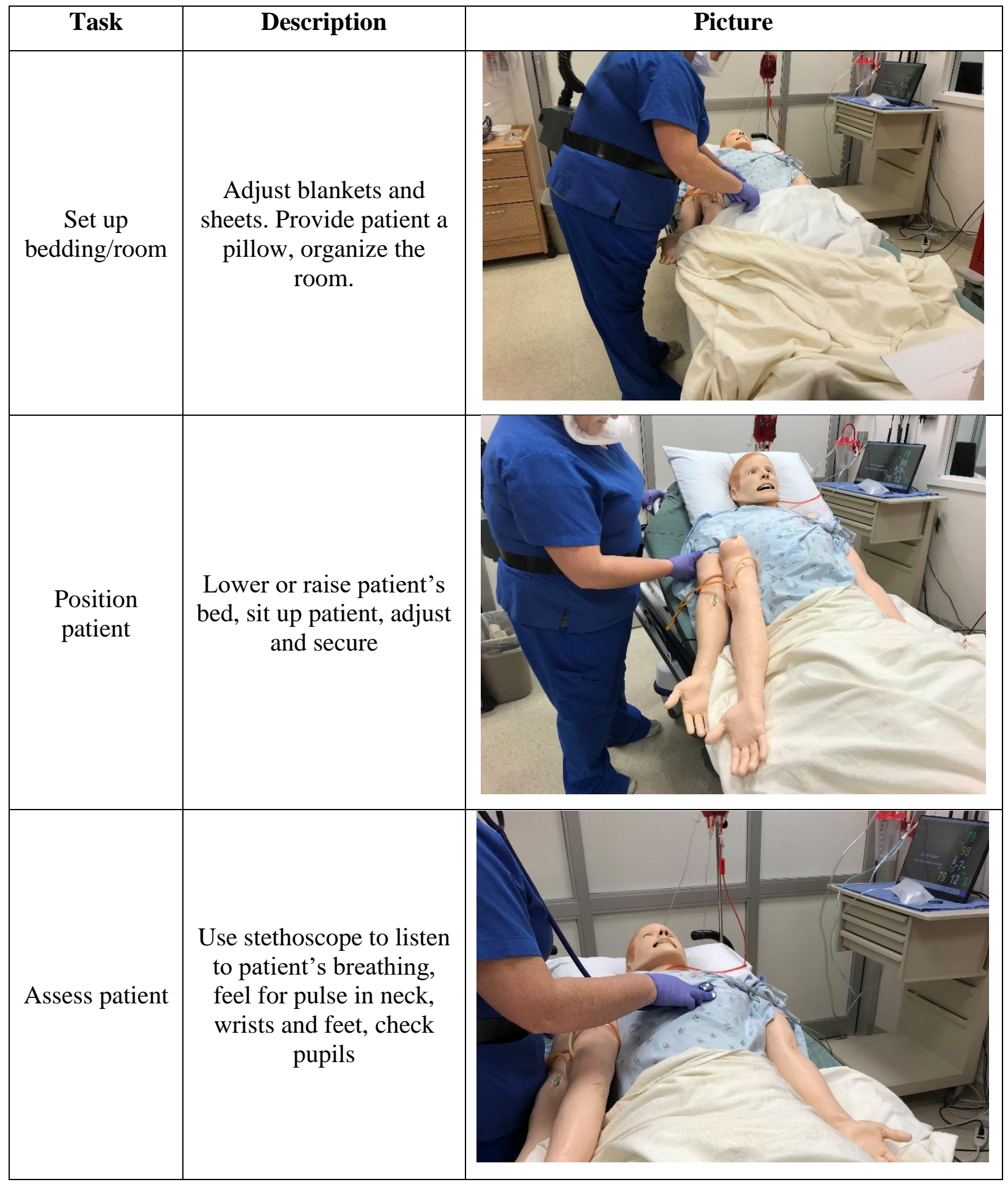




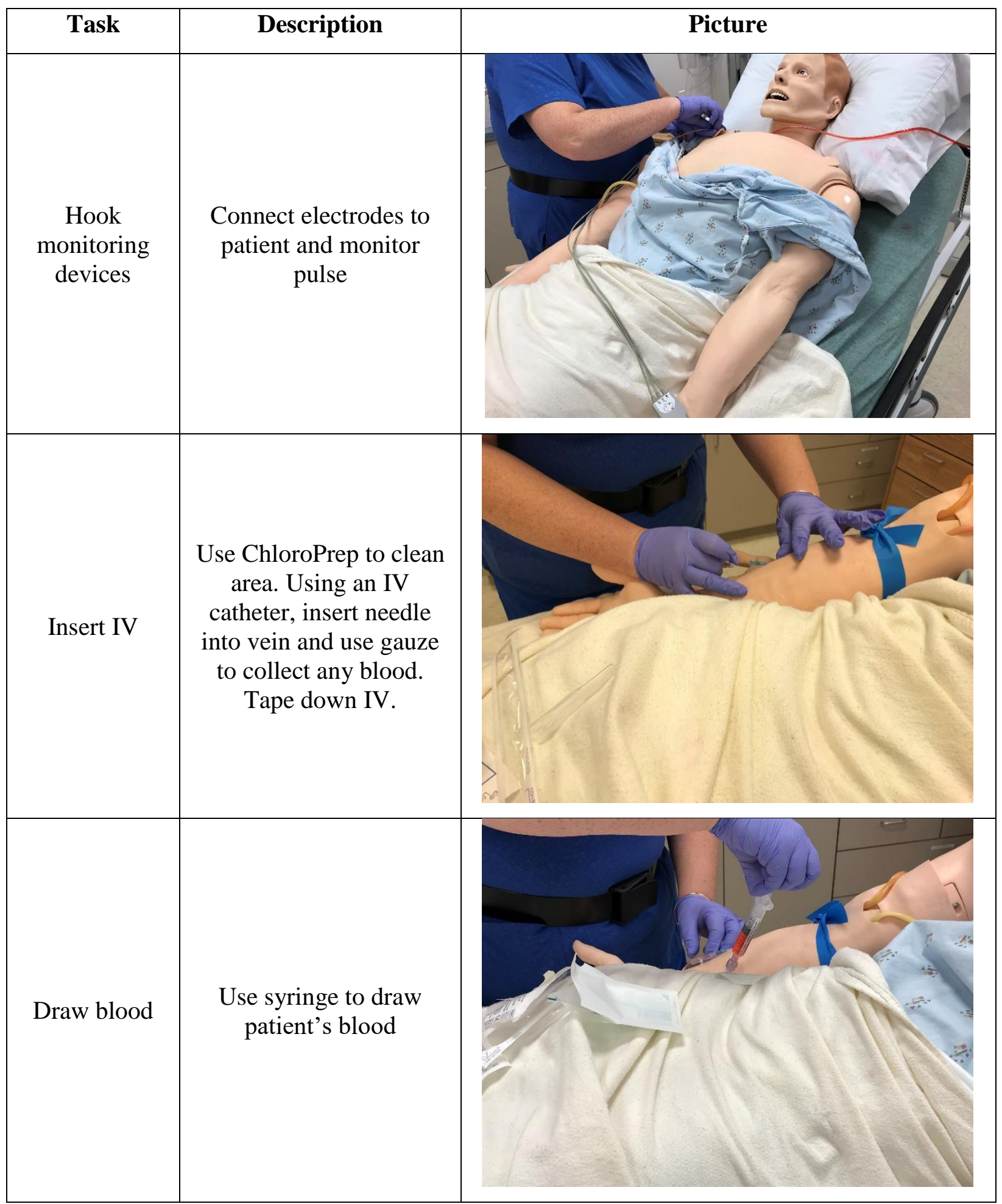




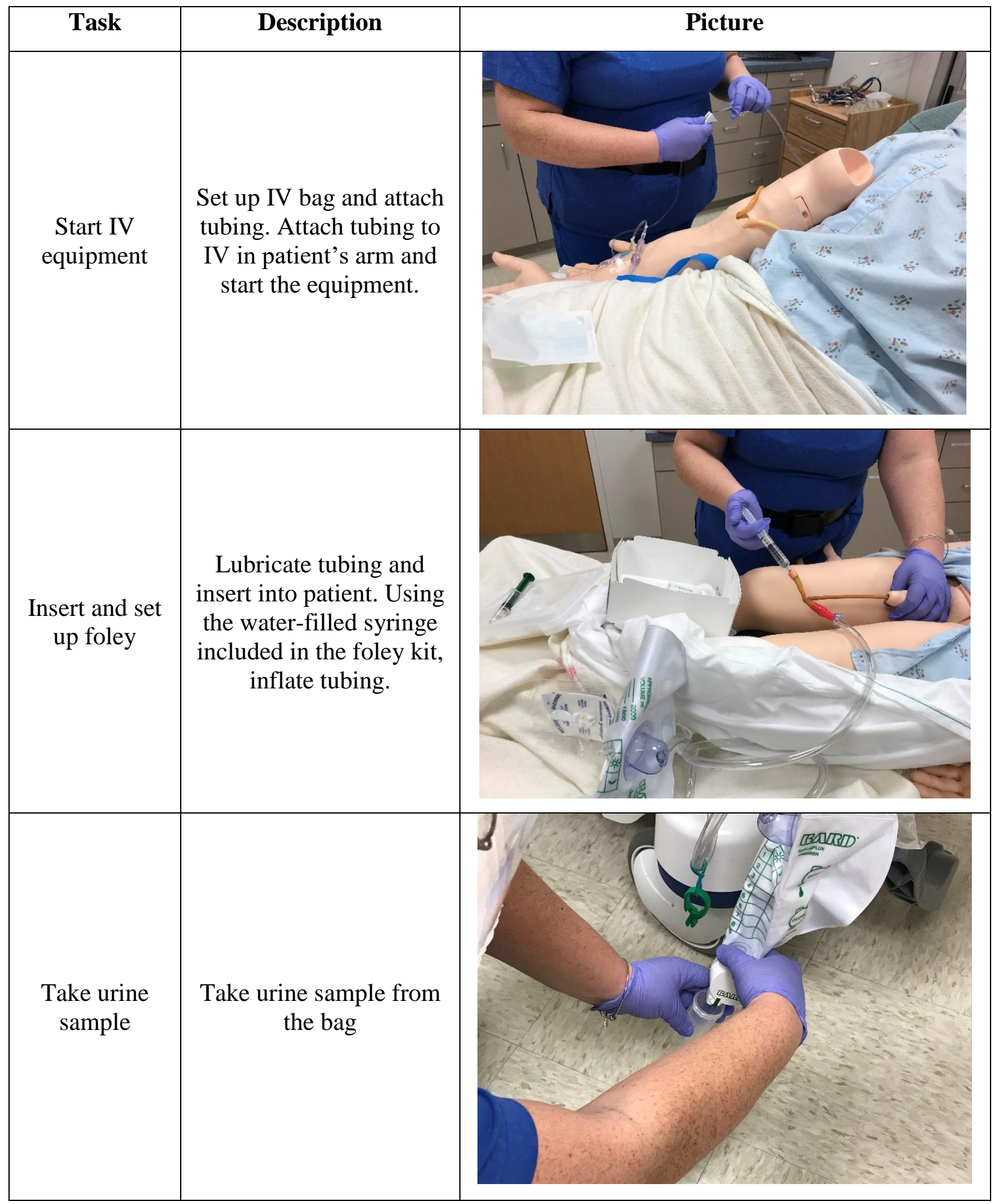




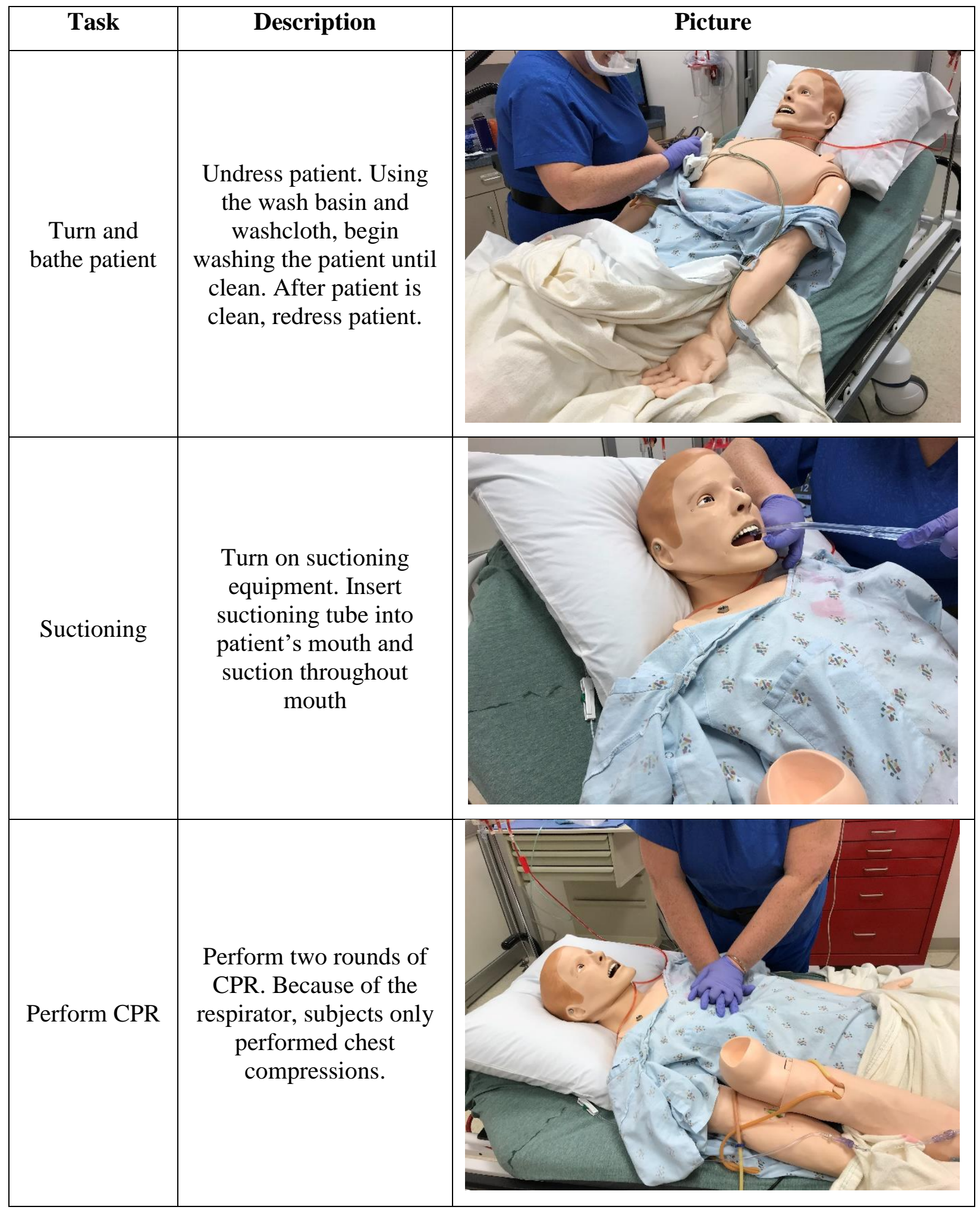




\subsubsection{Respirator Evaluation}

Each subject was given a survey to answer about each respirator after the tasks were performed. Appendix B is an example copy of the survey given to the subjects. The survey requests basic information about the subject and it was also used to record start and stop times for each respirator. The subject was asked to indicate on a scale how they would evaluate the respirator in 16 different categories, explained in the table below.

Table 3 Evaluation Categories

\begin{tabular}{|c|c|}
\hline Category & Scale \\
\hline General comfort & $\begin{array}{l}\text { 1-6 with: } \\
1 \text { - Very poor } \\
\text { 2- Poor } \\
3 \text { - Acceptable } \\
4 \text { - Good } \\
\text { 5- Very good } \\
\text { 6- Excellent }\end{array}$ \\
\hline Inspiratory/expiratory effort & $\begin{array}{c}\text { 1-7 with: } \\
1 \text { - Not noticeable } \\
7 \text { - Intolerable } \\
\end{array}$ \\
\hline Overall breathing discomfort & $\begin{array}{c}\text { 1-6 with: } \\
1 \text { - Not at all } \\
2 \text { - Very slight } \\
3-\text { Slight } \\
4 \text { - Somewhat high } \\
5-\text { High } \\
\text { 6- Unbearable } \\
\end{array}$ \\
\hline Facial and body heat & $\begin{array}{c}\text { 1-6 with: } \\
1-\text { Not at all } \\
2 \text { - Very slight } \\
3-\text { Slight } \\
4 \text { - Somewhat high } \\
5-\text { High } \\
6 \text { - Unbearable }\end{array}$ \\
\hline Overall thermal comfort & $\begin{array}{c}\text { 1-10 with: } \\
1 \text { - Coldest you've ever been } \\
5 \text { - Neither hot nor cold } \\
10-\text { Hottest you have ever been }\end{array}$ \\
\hline Pressure or pain & $\begin{array}{c}\text { 1-6 with: } \\
1-\text { Not at all } \\
2-\text { Very slight } \\
3-\text { Slight } \\
4-\text { Somewhat high } \\
5-\text { High } \\
6-\text { Unbearable }\end{array}$ \\
\hline
\end{tabular}




\begin{tabular}{|c|c|}
\hline Category & Scale \\
\hline Eye discomfort & $\begin{array}{c}\text { 1-6 with: } \\
1 \text { - Not at all } \\
2 \text { - Very slight } \\
3-\text { Slight } \\
4 \text { - Somewhat high } \\
5-\text { High } \\
\text { 6-Unbearable }\end{array}$ \\
\hline $\begin{array}{l}\text { Interference with wearing } \\
\text { glasses/goggles contact lenses } \\
\text { (This was not completed if } \\
\text { subject does not wear these.) }\end{array}$ & $\begin{array}{c}\text { 1-6 with: } \\
1 \text { - Not at all } \\
2 \text { - Very slight } \\
3-\text { Slight } \\
\text { 4- Somewhat high } \\
5-\text { High } \\
\text { 6- Unbearable }\end{array}$ \\
\hline Clear line of vision & $\begin{array}{c}\text { 1-6 with: } \\
\text { 1-Very poor } \\
\text { 2- Poor } \\
\text { 3-Acceptable } \\
\text { 4-Good } \\
\text { 5- Very good } \\
6 \text { - Excellent } \\
\end{array}$ \\
\hline Difficulty of putting on & $\begin{array}{c}\text { 1-6 with: } \\
1 \text { - Not at all } \\
2 \text { - Very slight } \\
3-\text { Slight } \\
4 \text { - Somewhat high } \\
5-\text { High } \\
\text { 6-Unbearable }\end{array}$ \\
\hline Difficulty to operate & $\begin{array}{c}\text { 1-6 with: } \\
1 \text { - Not at all } \\
2 \text { - Very slight } \\
3-\text { Slight } \\
4 \text { - Somewhat high } \\
5-\text { High } \\
6 \text { - Unbearable }\end{array}$ \\
\hline $\begin{array}{c}\text { Mechanical interference with } \\
\text { duties }\end{array}$ & $\begin{array}{c}\text { 1-6 with: } \\
1 \text { - Not at all } \\
2-\text { Very slight } \\
3-\text { Slight } \\
\text { 4- Somewhat high } \\
5-\text { High } \\
\text { 6- Unbearable }\end{array}$ \\
\hline Exertion & $\begin{array}{c}\text { 6-20 with: } \\
\text { 6- No exertion at all } \\
20-\text { Maximal exertion }\end{array}$ \\
\hline
\end{tabular}




\begin{tabular}{|c|c|}
\hline Category & Scale \\
\hline $\begin{array}{c}\text { How many hours do you think } \\
\text { you could wear this respirator } \\
\text { continuously? }\end{array}$ & Written response \\
\hline & \\
\hline $\begin{array}{c}\text { Perceived efficiency against } \\
\text { biological hazards }\end{array}$ & $1-\mathbf{6}$ with: \\
& $2-$ Not at all \\
& $3-$ Slight \\
& $4-$ Somewhat high \\
Overall assessment & $5-$ High \\
& $6-$ Complete \\
\hline & $1-\mathbf{6}$ with: \\
& $1-$ Not at all \\
& $2-$ Very slight \\
& $3-$ Slight \\
& $4-$ Somewhat high \\
& $5-$ High \\
& $6-$ Unbearable \\
\hline
\end{tabular}

Subjects' vital signs were recorded both before and after the tasks. The tables to record these values were included on the evaluation form. The final page of the form was a questionnaire survey asking the subjects preferences on flow rates.

Table 4 PAPR Flow Rate Questions

\begin{tabular}{|c|c|}
\hline Question & Type of response \\
\hline $\begin{array}{c}\text { When performing the following tasks (deemed low risks), } \\
\text { do you prefer a lower flow rate for the following PAPR? }\end{array}$ & Yes or No for each PAPR listed \\
\hline $\begin{array}{c}\text { When performing the following tasks (deemed low risks), } \\
\text { do you think a lower flow rate is more acceptable? }\end{array}$ & Yes or No for each PAPR listed \\
\hline $\begin{array}{c}\text { When performing the following tasks (deemed low risks), } \\
\text { do you think a lower flow rate is more effective? }\end{array}$ & Yes or No for each PAPR listed \\
\hline
\end{tabular}

\subsection{Protocol}

Subjects were recruited and scheduled with the WV STEPS center depending on their availability. Before data collection could begin, subjects signed a consent form. The experiment and its minimal risk was explained to them during this time. This process occurred in a meeting room where the subjects would don respirators, give vitals and respond to the questionnaire. After the purpose of the study and the process were explained to them, subjects were given a 
brief introduction and orientation in the simulation room. This helped to ensure that the time spent with the first respirator was not affected by the subject lack of familiarity with the room.

After the orientation, the subjects returned to the donning room to don the first respirator. Respirators were randomized for each subject so that no subject would experience the same order of respirators each time. The purpose of this was to reduce bias against respirators based on their order. After donning the respirator, subjects' vitals were taken. Heart rate and blood oxygen levels were measured with the pulse oximeter while respiratory rate was self-reported by the subjects. Subjects were then escorted to the simulation room where they were asked to perform the 12 tasks listed in Table 2. Investigators were present in the room with the subjects during these tasks to answer questions and observe subject comfort levels. Performing the 12 tasks took approximately 15-20 minutes for each subject. Subjects were specifically instructed to spend at least 15 minutes performing the tasks in order for them to fully experience wearing the respirator.

After completing the tasks, each subject was escorted back to the donning room where vitals were recorded again. The subject would then remove the respirator and answer the questions relating to the respirator in the written survey sheets. Respirators were thoroughly cleaned during this time to ensure sanitary conditions to protect the subjects' health. After completing the questionnaire, subjects would then don the next respirator until all were complete.

\subsection{Data Analysis}

All data from the questionnaire forms was transferred into Excel. Data was divided into three groups: categorical, vitals and questionnaire (based on the flow rate questions). These three groups were analyzed separately with the categorical data being analyzed in RStudio and the vitals and questionnaire data in Excel. The raw data used for the analysis is located in Appendix C.

\subsubsection{Categorical Data Analysis}

The data was divided up into the 16 evaluation categories. Each category had three groups within, those being the MAXAIR, Air-Mate and Versaflo PAPRs. Because this data is categorical, normal distribution cannot be assumed. Thus, non-parametric tests were performed. In order to determine whether there were differences between the scores between the three 
PAPRs, the Kruskall-Wallis test was performed on each of the 16 categories. An $\alpha$-level of 0.05 was assumed and the null hypothesis was that the three PAPRs had the same distribution of scores. If results from the Kruskall-Wallis test proved significant, the Dunn test would then be performed to compare each PAPRs score to test for significance difference between the PAPR scores. The null hypothesis for the Dunn test was that there were no significant differences between groups and the $\alpha$-level was 0.05 . Three groups were being compared, so the degrees of freedom were 2. These non-parametric were all performed using the RStudio software.

\subsubsection{Vitals Data Analysis}

There were vitals data for each PAPR: heart rate, respiratory rate and blood oxygen levels. Vitals were taken before PAPR use and after PAPR use. Data was divided up into its respective category. These vitals, while small in sample size, are a part of a larger distribution of human data. Due to this fact, normal distribution was assumed allowing for parametric statistical tests to be used. Also, because this data was a before and after set, a Paired Two Sample for Means t-test was performed. A two-sided t-test was performed for each PAPR in each category, totaling nine results. The $\alpha$-level was 0.05 for these tests and the null hypothesis was that the two sets of data had equal means. If the results of the t-test were statistically significant, an ANOVA test was performed on all three PAPRs in order to determine if the differences in vitals before the test and after test were unequal between the three PAPRs. The $\alpha$-level was 0.05 for these tests as well and the null hypothesis was that the changes in heart rate were equal between the three PAPRs.

\subsubsection{Questionnaire Data Analysis}

The questionnaire data was an evaluation on preference comparing low flow rates with high flow rates for low-risk tasks. These were yes or no responses to the each of the three questions which are described in Table 4. For each PAPR, frequency percentages were calculated for yes and no answers. 


\section{Chapter 4: Results}

The purpose of this study was to determine the differences in perceived comfort, acceptability and efficiency between the three different PAPRs: MAXAIR, Air-Mate and Versaflo.

\subsection{PAPR Evaluation}

Each of the three PAPRS were evaluated with 16 categories by 8 different subjects. A summary of these results for each PAPR is provided in Table 5-7. These summaries contain the mean, standard deviation, minimum value and maximum value for each category for each PAPR.

Table 5 MAXAIR PAPR Descriptive Results

\begin{tabular}{|c|c|c|c|c|}
\hline Category & Mean & Standard Deviation & Minimum & Maximum \\
\hline General comfort & 4.75 & 0.886 & 3 & 6 \\
\hline $\begin{array}{l}\text { Inspiratory/expiratory } \\
\text { effort }\end{array}$ & 1.38 & 0.518 & 1 & 2 \\
\hline $\begin{array}{l}\text { Overall breathing } \\
\text { discomfort }\end{array}$ & 1.25 & 0.463 & 1 & 2 \\
\hline Facial and body heat & 1.88 & 0.641 & 1 & 3 \\
\hline Overall thermal comfort & 5.00 & 0.926 & 4 & 7 \\
\hline Pressure or pain & 1.38 & 0.744 & 1 & 3 \\
\hline Eye discomfort & 1.38 & 0.744 & 1 & 3 \\
\hline $\begin{array}{l}\text { Interference with wearing } \\
\text { glasses/goggles/contacts }\end{array}$ & 1.33 & 0.516 & 1 & 2 \\
\hline Clear line of vision & 4.63 & 1.06 & 3 & 6 \\
\hline Difficulty of putting on & 2.50 & 0.926 & 1 & 4 \\
\hline Difficulty to operate & 1.88 & 0.835 & 1 & 3 \\
\hline $\begin{array}{l}\text { Mechanical interference } \\
\text { with duties }\end{array}$ & 2.13 & 0.991 & 1 & 4 \\
\hline Exertion & 7.75 & 2.19 & 6 & 12 \\
\hline $\begin{array}{l}\text { How many hours could } \\
\text { you wear this respirator } \\
\text { continuously? }\end{array}$ & 3.63 & 2.00 & 2 & 8 \\
\hline $\begin{array}{l}\text { Perceived efficiency } \\
\text { against biological hazards }\end{array}$ & 4.13 & 1.13 & 3 & 6 \\
\hline Overall assessment & 2.00 & 0.756 & 1 & 3 \\
\hline
\end{tabular}

Note that general comfort and clear line of vision were scaled from 1 to 6 , with 6 being the best possible score. Inspiratory/expiratory effort was scaled from 1 to 7 with 1 being the best possible score. The categories for overall breathing discomfort, facial and body heat, pressure or pain, eye 
discomfort, interference with wearing glasses/goggles/contact lenses, difficulty of putting on, difficulty to operate, mechanical interference with duties, perceived efficiency against biological hazards and overall assessment were both scaled from 1 to 6 with 1 being the best possible score. Overall thermal comfort was scaled from 1 to 10 with 5 indicating the most comfortable.

Exertion was scaled from 6 to 20 with 6 being the best possible score. The question "How many hours do you think you could wear this respirator continuously?" was a written response with a higher number being best.

Table 6 Air-Mate PAPR Descriptive Results

\begin{tabular}{|l|c|c|c|c|}
\hline \multicolumn{1}{|c|}{ Category } & Mean & Standard Deviation & Minimum & Maximum \\
\hline General comfort & 3.88 & 0.835 & 3 & 5 \\
\hline $\begin{array}{l}\text { Inspiratory/expiratory } \\
\text { effort }\end{array}$ & 2.00 & 1.07 & 1 & 4 \\
\hline $\begin{array}{l}\text { Overall breathing } \\
\text { discomfort }\end{array}$ & 1.75 & 0.707 & 1 & 3 \\
\hline Facial and body heat & 2.25 & 1.06 & 1 & 4 \\
\hline Overall thermal comfort & 5.13 & 0.835 & 4 & 7 \\
\hline Pressure or pain & 1.50 & 0.756 & 1 & 3 \\
\hline Eye discomfort & 1.25 & 0.463 & 1 & 2 \\
\hline $\begin{array}{l}\text { Interference with wearing } \\
\text { glasses/goggles/contacts }\end{array}$ & 1.50 & 0.548 & 1 & 2 \\
\hline Clear line of vision & 3.25 & 0.886 & 2 & 5 \\
\hline Difficulty of putting on & 3.13 & 0.991 & 2 & 4 \\
\hline Difficulty to operate & 2.25 & 1.06 & 1 & 3 \\
\hline $\begin{array}{l}\text { Mechanical interference } \\
\text { with duties }\end{array}$ & 2.13 & 0.835 & 6 & 12 \\
\hline Exertion & 9.00 & 2.20 & 1 & 4 \\
\hline $\begin{array}{l}\text { How many hours could } \\
\text { you wear this respirator } \\
\text { continuously? }\end{array}$ & 2.13 & 1.13 & 1 & 5 \\
\hline $\begin{array}{l}\text { Perceived efficiency } \\
\text { against biological hazards }\end{array}$ & 3.88 & 0.991 & 0.756 & 3 \\
\hline Overall assessment & 2.50 & & & 4 \\
\hline
\end{tabular}

Table 7 Versaflo PAPR Descriptive Results

\begin{tabular}{|l|c|c|c|c|}
\hline Category & Mean & Standard Deviation & Minimum & Maximum \\
\hline General comfort & 3.88 & 0.835 & 3 & 5 \\
\hline
\end{tabular}




\begin{tabular}{|c|c|c|c|c|}
\hline Category & Mean & Standard Deviation & Minimum & Maximum \\
\hline $\begin{array}{l}\text { Inspiratory/expiratory } \\
\text { effort }\end{array}$ & 2.00 & 1.07 & 1 & 4 \\
\hline $\begin{array}{l}\text { Overall breathing } \\
\text { discomfort }\end{array}$ & 1.75 & 0.707 & 1 & 3 \\
\hline Facial and body heat & 2.25 & 1.04 & 1 & 4 \\
\hline Overall thermal comfort & 5.13 & 0.835 & 4 & 7 \\
\hline Pressure or pain & 1.50 & 0.756 & 1 & 3 \\
\hline Eye discomfort & 1.25 & 0.463 & 1 & 2 \\
\hline $\begin{array}{l}\text { Interference with wearing } \\
\text { glasses/goggles/contacts }\end{array}$ & 1.50 & 0.548 & 1 & 2 \\
\hline Clear line of vision & 3.25 & 0.886 & 2 & 5 \\
\hline Difficulty of putting on & 3.13 & 0.991 & 2 & 5 \\
\hline Difficulty to operate & 2.25 & 1.04 & 1 & 4 \\
\hline $\begin{array}{l}\text { Mechanical interference } \\
\text { with duties }\end{array}$ & 2.13 & 0.835 & 1 & 3 \\
\hline Exertion & 9.00 & 2.20 & 6 & 12 \\
\hline $\begin{array}{l}\text { How many hours could } \\
\text { you wear this respirator } \\
\text { continuously? }\end{array}$ & 2.13 & 1.13 & 0.25 & 4 \\
\hline $\begin{array}{l}\text { Perceived efficiency } \\
\text { against biological hazards }\end{array}$ & 3.88 & 0.991 & 3 & 5 \\
\hline Overall assessment & 2.50 & 0.756 & 1 & 3 \\
\hline
\end{tabular}

For the categories analyzed, the category "Exertion" had the largest variation in its scores. This is partially due to the large range of numbers that the subject could select which was 6-20. The question "How many hours could you wear this respirator continuously?" also experienced a larger variation as subjects could write in whatever number they preferred. These ranged from 0.25 hours to 8 hours. The categories with the least amount of variation and the smallest ranges were the categories "Eye discomfort" and "Interference with wearing glasses/goggles/contacts."

This data was then reformatted and transferred to RStudio for the nonparametric statistical test. The $\alpha$-level for the Kruskall-Wallis test was 0.05 and the test was performed on all categories. The results from the Kruskall-Wallis test for each category are shown in the table below. 
Table 8 Kruskall-Wallis Test Results for Categorical Data

\begin{tabular}{|c|c|c|c|}
\hline Category & Chi-Squared Result & p-value & Hypothesis \\
\hline General comfort & 9.51 & 0.009 & Reject null $(\mathrm{p}<0.05)$ \\
\hline Inspiratory/expiratory effort & 5.59 & 0.062 & $\begin{array}{c}\text { Fail to reject null } \\
(p>0.05)\end{array}$ \\
\hline $\begin{array}{l}\text { Overall breathing } \\
\text { discomfort }\end{array}$ & 7.68 & 0.022 & Reject null $(\mathrm{p}<0.05)$ \\
\hline Facial and body heat & 1.64 & 0.440 & $\begin{array}{l}\text { Fail to reject null } \\
\qquad(p>0.05)\end{array}$ \\
\hline Overall thermal comfort & 0.62 & 0.973 & $\begin{array}{l}\text { Fail to reject null } \\
\quad(p>0.05)\end{array}$ \\
\hline Pressure or pain & 2.77 & 0.251 & $\begin{array}{l}\text { Fail to reject null } \\
\quad(p>0.05)\end{array}$ \\
\hline Eye discomfort & 1.78 & 0.411 & $\begin{array}{l}\text { Fail to reject null } \\
\quad(p>0.05)\end{array}$ \\
\hline $\begin{array}{l}\text { Interference with wearing } \\
\text { glasses/goggles/contacts }\end{array}$ & 2.33 & 0.312 & $\begin{array}{l}\text { Fail to reject null } \\
(p>0.05)\end{array}$ \\
\hline Clear line of vision & 7.64 & 0.022 & Reject null $(\mathrm{p}<0.05)$ \\
\hline Difficulty of putting on & 1.83 & 0.400 & $\begin{array}{l}\text { Fail to reject null } \\
(\mathrm{p}>0.05)\end{array}$ \\
\hline Difficulty to operate & 5.42 & 0.067 & $\begin{array}{l}\text { Fail to reject null } \\
\quad(p>0.05)\end{array}$ \\
\hline $\begin{array}{l}\text { Mechanical interference } \\
\text { with duties }\end{array}$ & 6.49 & 0.039 & Reject null $(\mathrm{p}<0.05)$ \\
\hline Exertion & 3.62 & 0.164 & $\begin{array}{l}\text { Fail to reject null } \\
\quad(p>0.05)\end{array}$ \\
\hline $\begin{array}{l}\text { How many hours could you } \\
\text { wear this respirator } \\
\text { continuously? }\end{array}$ & 6.67 & 0.036 & Reject null $(\mathrm{p}<0.05)$ \\
\hline $\begin{array}{l}\text { Perceived efficiency against } \\
\text { biological hazards }\end{array}$ & 1.24 & 0.537 & $\begin{array}{l}\text { Fail to reject null } \\
\quad(p>0.05)\end{array}$ \\
\hline Overall assessment & 5.52 & 0.063 & $\begin{array}{l}\text { Fail to reject null } \\
(p>0.05)\end{array}$ \\
\hline
\end{tabular}

Of the 16 categories, the results from the Kruskall-Wallis test indicated that a total of five did not have the same distribution $(\mathrm{p}<0.05)$. The 5 categories with significant results were: general comfort, overall breathing discomfort, clear line of vision, mechanical interference with duties and how many hours could you wear this respirator continuously? There were also 3 categories with p-values that were very close to the $\alpha$-level: inspiratory/expiratory effort, difficulty to operate and overall assessment. 
The 5 categories where the null hypothesis was rejected were then analyzed further with Dunn's test. The $\alpha$-level for the Dunn test was 0.05. The results of this test are shown in the table below.

Table 9 Dunn Test Results for Categorical Data

\begin{tabular}{|c|c|c|c|c|}
\hline Category & Comparison & Z-value & p-value & Hypothesis \\
\hline \multirow{3}{*}{ General comfort } & Air-Mate to MAXAIR & -1.51 & 0.129 & $\begin{array}{l}\text { Fail to reject null } \\
(p>0.05)\end{array}$ \\
\hline & Air-Mate to Versaflo & 1.57 & 0.175 & $\begin{array}{l}\text { Fail to reject null } \\
(p>0.05)\end{array}$ \\
\hline & MAXAIR to Versaflo & 3.08 & 0.006 & $\begin{array}{l}\text { Reject null } \\
(\mathrm{p}<0.05)\end{array}$ \\
\hline \multirow{3}{*}{$\begin{array}{l}\text { Overall breathing } \\
\text { discomfort }\end{array}$} & Air-Mate to MAXAIR & 1.36 & 0.175 & $\begin{array}{l}\text { Fail to reject null } \\
(p>0.05)\end{array}$ \\
\hline & Air-Mate to Versaflo & -1.41 & 0.236 & $\begin{array}{l}\text { Fail to reject null } \\
(p>0.05)\end{array}$ \\
\hline & MAXAIR to Versaflo & -2.77 & 0.017 & $\begin{array}{l}\text { Reject null } \\
(\mathrm{p}<0.05)\end{array}$ \\
\hline \multirow{3}{*}{ Clear line of vision } & Air-Mate to MAXAIR & -2.58 & 0.030 & $\begin{array}{l}\text { Reject null } \\
(p<0.05)\end{array}$ \\
\hline & Air-Mate to Versaflo & -0.43 & 0.670 & $\begin{array}{l}\text { Fail to reject null } \\
(p>0.05)\end{array}$ \\
\hline & MAXAIR to Versaflo & 2.15 & 0.047 & $\begin{array}{l}\text { Reject null } \\
(\mathrm{p}<0.05)\end{array}$ \\
\hline \multirow{3}{*}{$\begin{array}{l}\text { Mechanical } \\
\text { interference with duties }\end{array}$} & Air-Mate to MAXAIR & 0.110 & 0.912 & $\begin{array}{l}\text { Fail to reject null } \\
(p>0.05)\end{array}$ \\
\hline & Air-Mate to Versaflo & -2.15 & 0.047 & $\begin{array}{l}\text { Reject null } \\
(p<0.05)\end{array}$ \\
\hline & MAXAIR to Versaflo & -2.26 & 0.072 & $\begin{array}{l}\text { Fail to reject null } \\
(\mathrm{p}>0.05)\end{array}$ \\
\hline \multirow{3}{*}{$\begin{array}{l}\text { How many hours could } \\
\text { you wear this respirator } \\
\text { continuously? }\end{array}$} & Air-Mate to MAXAIR & -1.78 & 0.113 & $\begin{array}{l}\text { Fail to reject null } \\
(p>0.05)\end{array}$ \\
\hline & Air-Mate to Versaflo & 0.73 & 0.464 & $\begin{array}{l}\text { Fail to reject null } \\
(p>0.05)\end{array}$ \\
\hline & MAXAIR to Versaflo & 2.51 & 0.036 & $\begin{array}{l}\text { Reject null } \\
(\mathrm{p}<0.05)\end{array}$ \\
\hline
\end{tabular}

Each category produced either one or two significant results. For general comfort, the MAXAIR compared to the Versaflo yielded significant results. For this category, the mean for MAXAIR was 4.75 and the mean for the Versaflo was 2.86. The Versaflo also had a larger range of responses with a minimum of 1 and a maximum of 5. In this particular category, a higher 
score is more favorable. The MAXAIR was found to be significantly more favorable when compared to the Versaflo in general comfort. Similarly, in the overall breathing discomfort category, the Dunn test results indicated that MAXAIR and Versaflo experienced a significant difference. The mean score for MAXAIR in this category was 1.25 and for the Versaflo it was 2.75. Again, the Versaflo had a larger range of responses with a minimum of 1 and a maximum of 5 while the MAXAIR had a minimum of 1 and a maximum of 2. In this particular category, a lower average score would indicate less overall breathing discomfort and would be the more favorable. Thus, the Versaflo was rated as having more overall breathing discomfort than the MAXAIR.

The clear line of vision category yielded two significant results. The first was in comparing Air-Mate to MAXAIR and the second was in comparing MAXAIR to Versaflo. Comparing Air-Mate to Versaflo, however, did not yield any significant results. For this category, the mean score for MAXAIR was 4.63, the mean score for Air-Mate was 3.25 and the mean score for Versaflo was 3.38. For this particular category, higher scores indicating a more favorable rating. In this comparison, MAXAIR's score was significantly more favorable than Air-Mate or Versaflo.

The mechanical interference with duties category had one significant result and another result that was very close to being less than the $\alpha$-level. The Air-Mate to Versaflo comparison yielded a significant result while the MAXAIR to Versaflo was very close to being significant $(\mathrm{p}=0.072)$. Furthermore, MAXAIR and Air-Mate had the exact same mean of 2.13. However, MAXAIR had a higher standard deviation. Even though the means were the same, the distribution of values was slightly different. The Versaflo scores produced a mean of 3.5. In this category, a lower score is more favorable and thus the results show that the Air-Mate tended to have less mechanical interference with duties than the Versaflo. Finally, the last category asked, "How many hours could you wear this respirator continuously?" The comparison of the MAXAIR to the Versaflo produced significant results. The mean number of hours that subjects reported was 4.13 for MAXAIR and 1.66 for Versaflo. In this category, a larger average would indicate that the subject could wear the PAPR for longer, which would be more favorable. In this case, the MAXAIR was shown to be significantly better than the Versaflo in regard to how long a subject was willing to wear the PAPR. 
Overall, the MAXAIR performed better than the other PAPRs. The Air-Mate had only one result where it performed better than the other PAPRs. Typically, the PAPR to which the others had significant differences from was the Versaflo, which in all but one case that were significant, performed the worst out of the three. The only case in which the Versaflo did not perform the worst was the clear line of vision category, in which the Air-Mate performed the worst. There was only one instance where MAXAIR differed significantly from Air-Mate and that was in the clear line of vision category. Otherwise, the MAXAIR and Air-Mate tended to follow similar distributions and have similar means.

\subsection{Vitals}

Each PAPR had a "before" and "after" measurement of vitals for each subject. For MAXAIR, the first subject's "before" vitals were not taken and thus, for MAXAIR, there were only 7 observations included in the paired two sample t-test. The null hypothesis for each paired t-test for each vital was that the difference in the "before" mean from the "after" mean was equal to 0 . The $\alpha$-level for each test was 0.05 and the p-value reported was two tailed. The results of the paired t-tests for each PAPR are shown in the tables below.

Table 10 MAXAIR Vitals Paired Two Sample T-Test Results

\begin{tabular}{|l|c|c|l|}
\hline \multicolumn{1}{|c|}{ Vital } & T-value & p-value & \multicolumn{1}{c|}{ Hypothesis } \\
\hline Heart Rate & -7.12 & 0.0004 & Reject null $(\mathrm{p}<0.05)$ \\
\hline Respiratory Rate & -1.55 & 0.172 & Fail to reject null $(\mathrm{p}>0.05)$ \\
\hline Blood Oxygen Level & 1.00 & 0.356 & Fail to reject null $(\mathrm{p}>0.05)$ \\
\hline
\end{tabular}

Table 11 Air-Mate Vitals Paired Two Sample T-Test Results

\begin{tabular}{|l|c|c|l|}
\hline \multicolumn{1}{|c|}{ Vital } & T-value & p-value & \multicolumn{1}{|c|}{ Hypothesis } \\
\hline Heart Rate & -3.53 & 0.010 & Reject null $(\mathrm{p}<0.05)$ \\
\hline Respiratory Rate & 0.146 & 0.888 & Fail to reject null $(\mathrm{p}>0.05)$ \\
\hline Blood Oxygen Level & 0.607 & 0.563 & Fail to reject null $(\mathrm{p}>0.05)$ \\
\hline
\end{tabular}


Table 12 Versiflo Vitals Paired Two Sample T-Test Results

\begin{tabular}{|l|c|c|l|}
\hline \multicolumn{1}{|c|}{ Vital } & T-value & p-value & \multicolumn{1}{c|}{ Hypothesis } \\
\hline Heart Rate & -4.75 & 0.002 & Reject null $(\mathrm{p}<0.05)$ \\
\hline Respiratory Rate & 0 & 1 & Fail to reject null $(\mathrm{p}>0.05)$ \\
\hline Blood Oxygen Level & -0.607 & 0.563 & Fail to reject null $(\mathrm{p}>0.05)$ \\
\hline
\end{tabular}

With each PAPR, the only significant result was produced by the heart rate data. The respiratory rate and blood oxygen level produced no significant results in any of the PAPRs. An ANOVA test was performed on the heart data with the null hypothesis stating that the mean differences between the three PAPRs were equal. The ANOVA test produced a p-value of 0.102, indicating a failure to reject the null hypothesis.

\subsection{PAPR Flow Rate Preferences}

The purpose of the final set of data was to determine if there were any differences in preferences between low flow rates and high flow rates for low risk tasks. The results are reported as frequency in the table below.

Table 13 Comparing High Flow Rate to Low Flow Rate Preferences and Acceptability Results

\begin{tabular}{|l|c|c|c|}
\hline \multicolumn{1}{|c|}{ Question } & PAPR & Yes & No \\
\hline $\begin{array}{l}\text { When performing the } \\
\text { following tasks } \\
\text { (deemed low risks), do }\end{array}$ & MAXAIR & $37.5 \%$ & $62.5 \%$ \\
\cline { 2 - 4 } $\begin{array}{l}\text { you prefer a lower flow } \\
\text { rate for the following }\end{array}$ & Air-Mate & $50 \%$ & $50 \%$ \\
\cline { 2 - 4 } PAPR? & Versaflo & $50 \%$ & $50 \%$ \\
\hline $\begin{array}{l}\text { When performing the } \\
\text { following tasks } \\
\text { (deemed low risks), do }\end{array}$ & MAXAIR & $50 \%$ & $50 \%$ \\
\cline { 2 - 4 } $\begin{array}{l}\text { you think a lower flow } \\
\text { rate is more } \\
\text { acceptable? }\end{array}$ & Air-Mate & $62.5 \%$ & $37.5 \%$ \\
\cline { 2 - 4 } $\begin{array}{l}\text { When performing the } \\
\text { following tasks } \\
\text { (deemed low risks), do }\end{array}$ & Versaflo & $50 \%$ & $50 \%$ \\
\cline { 2 - 4 } $\begin{array}{l}\text { you think a lower flow } \\
\text { rate is more effective? }\end{array}$ & Mersaflo & $37.5 \%$ & $62.5 \%$ \\
\cline { 2 - 4 } & & $50 \%$ & $60 \%$ \\
\hline
\end{tabular}


Most subjects preferred that the MAXAIR not have a lower flow rate, even for low risk tasks. Only $37.5 \%$ answered yes to both preferring a lower flow rate and believing that a lower flow rate is more effective. In addition, $62.5 \%$ of subjects believed that a lowered flow rate is more acceptable for the Air-Mate. Other than that, the results to these questions are somewhat inconclusive as most responses were $50 \%$ for both answers with only a few exceptions. 


\section{Chapter 5: Discussion}

\subsection{PAPR Evaluation with Categorical Data}

Only 5 out of the 16 categories for PAPR evaluation were found to have significant differences in distribution between the three PAPRs. These categories were general comfort, overall breathing discomfort, clear line of vision, mechanical interference with duties and the number of hours a subject was willing to wear the PAPR. In all but one category, the MAXAIR was the highest performing PAPR. The exception to this trend was the mechanical interference category in which the Air-Mate performed the best overall.

In nearly all categories, however, the Versaflo performed relatively worse than the other PAPRs. The only category in which the Versaflo was not the worst performing PAPR was the clear line of vision category, in which Air-Mate performed relatively worse. The number of hours that subjects were willing to wear the Versaflo averaged to 1.66, compared to the much higher values of 3.63 for MAXAIR and 2.13 for Air-Mate. This smaller average indicates that the subjects perceived the Versaflo to be more cumbersome to wear for long periods of time. One subject, who vocalized her issues with the Versaflo's design while donning the PAPR and during the tasks, stated on the survey form that she was only willing to wear the Versaflo for 0.25 hours or 15 minutes.

Some subjects even vocalized discomfort when wearing the Versaflo during data collection. The Versaflo had a double shrouded hood much like the more preferred MAXAIR, but the battery pack which supplied the air was the heaviest, weighing a total of approximately 4.5 pounds, and was seemingly more cumbersome than the other two PAPRs due to the size of the battery pack itself. One subject even vocalized that she believed she could not perform her duties properly in an emergency situation because she felt that the Versaflo was hindering her movement. The Versaflo received an average score of 3.5 in the mechanical interference category, while the other two PAPRs both received average scores of 2.13. The difference in the Versaflo from the others in this category is significant, indicating that a problem in the Versaflo design was causing this perception of mechanical interference with duties.

In the general comfort category, the MAXAIR performed significantly better at an average score of 4.75. The Air-Mate received a smaller average of 3.88, but its distribution of 
scores was not found to be significantly different from the MAXAIR. The Versaflo received a significantly lower score of 2.63. The MAXAIR was perceived to be generally comfortable to wear while the subjects perceived the Versaflo was significantly less comfortable to wear. These results are similar to the results to the question "How many hours could you wear this respirator continuously?" The subjects felt that they were unable to wear the Versaflo for long periods of time as they perceived the device as more cumbersome to wear. This relates to the result that the Versaflo scored significantly worse in general comfort. This significant difference in perceptions of comfort between the Versaflo and the other PAPRs is an important finding. The MAXAIR's less bulky design, weighing only about 2.5 pounds and adjustable helmet was perceived as more comfortable and subjects were willing to wear the MAXAIR for much longer. Furthermore, subjects perceived both the MAXAIR and the Air-Mate as interfering less with their duties. The Versaflo has a much bulkier, approximately 4.5 pound battery pack which must be worn as a belt, and a tighter, less open hood. This was perceived as less comfortable and that it was interfering with duties. The mechanical interference with duties, lower perception of general comfort and less willingness to wear the Versaflo for long periods of time are important design issues that could possibly be improved to reduce strain on HCW and increase acceptability.

Compared to the MAXAIR, both the Air-Mate and the Versaflo performed significantly worse in the clear line of vision category. The Air-Mate scored the worst at 3.25, whereas the Versaflo scored closely at 3.38. This was compared to the MAXAIR's much higher average score of 4.63. The designs of the PAPRs may be the cause of these significant differences. The MAXAIR is donned like a helmet and the hood is tightly fitted around the helmet, which opens up the line of vision. The Air-Mate and Versaflo, however, have hoods that are worn and then connected to a flexible hose on the battery pack. The plastic shielding which allows for the HCW to see is therefore not as open and can cause blind spots in the HCW's vision. Depending on the size of the HCW's head and their hair can also cause a tight space in the hoods of these two PAPRs, further decreasing the line of vision. The MAXAIR is able to be adjusted to fit a large range of head shapes and hair styles and the helmet design increases the distance between the forehead and the plastic shielding, further increasing the line of sight for the HCW. This perception of a decrease in vision is a significant issue in design of both the Versaflo and the AirMate. 
In the overall breathing discomfort category, results followed a similar trend as well. The MAXAIR performed the best with the lowest average score of 1.25 and the Dunn test yielded significant differences between the MAXAIR distribution of scores and the Versaflo distribution of scores. The Air-Mate scored an average of 1.75 which is similar to the MAXAIR score but the Versaflo scored a much higher average of 2.75. This result is very significant as these respirators are designed to protect HCWs by supplying clean air to them and it is important to ensure HCWs are comfortable breathing in these devices. The subjects reported, however, that they experienced some level of breathing discomfort when wearing the Versaflo. This again may be due to the heavier battery back and the tighter and more rigid hood. The extra physical strain due to the heavier battery back may have contributed to the perception of breathing discomfort that the subjects experienced. This possible issue of Versaflo design is very important as it relates to the function and purpose of the PAPR itself.

In the evaluation categories, the MAXAIR on average scored better than the other PAPRs. A possible explanation of why many subjects preferred this PAPR is that it is commonly used in the WVU healthcare system. Subjects recognized and were pleased to see the MAXAIR when they were asked to wear it for the data collection. Most subjects knew immediately how to wear and operate the MAXAIR. Because of this, there may be a bias in the scoring of the MAXAIR. However, despite this possible bias, in most significant categories, there was no statistically significant difference in distribution between the MAXAIR and the Air-Mate, indicating that the perceptions of these two PAPRs were similar.

The significant categories that were found in this study were somewhat different than the results found in the few other PAPR studies. Results from the Johnson et al study found subjects reporting thermal discomfort and breathing discomfort. However, these resulted from a decrease in flow rate due to a low battery charge. PAPRs in this study were monitored to ensure they were well charged so that flow rates would stay the same between subjects. Despite this, breathing discomfort was a significant category in this study, but thermal discomfort was not. Perceived thermal discomfort due to forehead temperature was also a result of the 2017 study by Powell et al. It was also reported that subjects complained of eye dryness as well (Powell et al, 2017). However, in this study, the two categories eye discomfort and interference with wearing glasses/goggles/contacts yielded no significant results. 


\subsection{Vitals}

Out of the three types of vitals taken, only the heart rate yielded significant results $(\mathrm{p}<0.05)$. The respiratory rate and the blood oxygen level did not produce any significant results. The heart rate data was significant for each PAPR. However, this is most likely due to how the experiment was organized. The "before" measurement of heart rate was performed while subject was at rest and the "after" measurement was performed after the final task, which was CPR, and after walking back to the donning room. Because of this, heart rate would naturally be higher because the subject was active. This is further supported by the ANOVA test result finding no significant difference between the heart rate increase between the three PAPRs. These results are also similar to those of a study performed by Powell et al in 2017. The results of that study discovered that heart rate, respiratory rate and blood oxygen level were not impacted by N95 or PAPR use. The authors theorize that the work rate impact these parameters more, rather than respirator use. This would explain why the heart rate was significant, but the other parameters were not. The work rate of the activities and the movement of the subject prior to recording vitals is the most likely cause for the increase heart rate. While the heart rate vitals produced statistically significant results, it has no impact within the context of this study.

\subsection{PAPR Flow Rate Preferences}

The results of the three questions relating to lower flow rate preferences did not yield much significance. Most of the answers were split at 50\% between "Yes" and "No" answers. However, most subjects (68\%) preferred the MAXAIR at a higher flow rate and felt that a higher flow rate would be more effective. This was the only significant result in this set of questions. Overall, subjects were mixed on their feelings of lower flow rates for each PAPR. This may possibly be due to some subjects not fully understanding the question. While these questions were explained to the subject during data collection, the wording of the question or possibly a misunderstanding of what was meant by "flow rate" may have caused the subjects to not answer the question accurately.

\subsection{Limitations}

The small sample size for this experiment was a strong limitation of this study. Only 8 subjects were a part of the sample. For a stronger study, the sample size should be increased to 
30-35 subjects. A larger sample size may cause more categories and vitals to yield statistically significant results. It may also produce more drastically different frequency percentages for the PAPR flow rate preference.

During the study, there were sometimes issues with more experienced subjects finishing the assign tasks too quickly. To rectify this, more tasks should be added. These could include tasks which require the subject to move around the room more, kneel on the ground or respond quickly to an emergency or issue. These more active tasks may more accurately represent a typical work day and help measure any possible inconvenience wearing a PAPR would cause in these situations. Increasing or decreasing the room temperature or humidity levels may also help to measure possible thermal comfort or discomfort the PAPRs may cause. These changing humidity levels and temperatures may also more accurately represent the different environments that a HCW may encounter when wearing a PAPR during the work day.

The PAPRs were only worn for a short period of time, only 15-20 minutes, which may not have allowed the subjects to fully experience wearing the device. Wearing the PAPRs for longer periods of time may cause other categories to become more significant. The addition of more tasks could potentially rectify this issue. The battery packs of the PAPRs were also unequal in weight. The Versaflo weighed 4.5 pounds, while the Air-Mate weighed 3.0 pounds and the MAXAIR weighed 2.5 pounds. This may have caused bias in the responses to the different PAPRs based on the weight of the battery pack. In future studies, PAPRs with similar weights but different models or shapes of the battery pack should be chosen. Additionally, future studies could also include measuring breathing rate of the subject as well as flow rate of the PAPRs. Finally, as mentioned in the discussion of the PAPR flow rate preferences, the questions pertaining to PAPR flow rate preferences may have been poorly worded and subjects may have misunderstood the question and its purpose. In future studies, these questions should be reworded to ensure that subjects are understanding and accurately responding to the questions.

\subsection{Conclusion}

Out of the three PAPRs studied, the MAXAIR performed the best in nearly every category and was preferred by most subjects. This may be due with the subjects' familiarity with the MAXAIR, but also may be due to the less cumbersome design of the device. On the other hand, the Versaflo performed relatively worse in nearly every category and was not often 
preferred by subjects. The 5 significant evaluation categories may explain its relatively poorer performance. Subjects found the Versaflo generally more uncomfortable, more cumbersome and were willing to wear it for less time than the other PAPRs. This may be due to its heavier battery pack causing more strain on the user and the hood design which subjects evaluated as decreasing their line of vision.

These results are important to evaluating the design and utilization of each PAPR. The significant categories may help to reevaluate PAPR design and seek out issues which may be negatively affecting HCWs who are sometimes required to wear these devices frequently and for long periods of time. The overall breathing discomfort category yielding significant results is especially cause for investigation into the Versaflo design as this could lead to more severe physiological strain on the HCW. These results could be used by PAPR manufacturers to understand the possible issues and shortcomings of the respirator design and make adjustments to improve the respiratory protection for the $\mathrm{HCWs}$ in the field. Future research will include comparison between MAXAIR PAPRs and N95 filtering facepiece respirators (FFR). 


\section{References}

1. Airgas - MSA10095181 - MSA Small OptimAir® Series Full Mask Air Purifying Respirator. (n.d.). Retrieved September 25, 2017, from http://www.airgas.com/product/Safety-Products/Respiratory-Protection/APR-Masks,Cartridges-\%26-Filters/p/MSA10095181

2. Bergman, M., Basu, R., Lei, Z., Niezgoda, G., \& Zhuang, Z. (2017). Development of a Manikin-Based Performance Evaluation Method for Loose-Fitting Powered. International Society for Respiratory Protection, 34(1), 40-57.

3. Best Practices for the Protection of Hospital-Based First Receivers from Mass Casualty Incidents Involving the Release of Hazardous Substances | Occupational Safety and Health Administration. (2005). Retrieved August 25, 2017, from https://www.osha.gov/dts/osta/bestpractices/html/hospital_firstreceivers.html\#39

4. CDC - NIOSH - NPPTL - Respirator Standards, Powered, Air-Purifying Respirators (PAPR) To Protect Emergency Responders Against CBRN Agents. (2003). Retrieved September 25, 2017, from https://www.cdc.gov/niosh/npptl/standardsdev/cbrn/papr/default.html

5. Cohen, H. J., Hecker, L. H., Mattheis, D. K., Johnson, J. S., Biermann, A. H., \& Foote, K. L. (2001). Simulated workplace protection factor study of powered air-purifying and supplied air respirators. AIHAJ : A Journal for the Science of Occupational and Environmental Health and Safety, 62(5), 595-604.

6. Crutchfield, C. D., Fairbank, E. O., \& Greenstein, S. L. (1999). Effect of Test Exercises and Mask Donning on Measured Respirator Fit. Applied Occupational and Environmental Hygiene, 14(12), 827-837. https://doi.org/10.1080/104732299302062

7. Gao, S., McKay, R. T., Yermakov, M., Kim, J., Reponen, T., He, X., ... Grinshpun, S. A. (2016). Performance of an improperly sized and stretched-out loose-fitting powered airpurifying respirator: Manikin-based study. Journal of Occupational and Environmental Hygiene, 13(3), 169-176. https://doi.org/10.1080/15459624.2015.1098780

8. Guidance on Personal Protective Equipment (PPE) To Be Used By Healthcare Workers during Management of Patients with Confirmed Ebola or Persons under Investigation (PUIs) for Ebola who are Clinically Unstable or Have Bleeding, Vomiting, or Diarrhea in U.S. (2015). Retrieved August 25, 2017, from https://www.cdc.gov/vhf/ebola/healthcareus/ppe/guidance.html

9. Hospital Respiratory Protection Program Toolkit Resources for Respirator Program Administrators. (2015). OSHA.

10. Johnson, A. T., Mackey, K. R., Scott, W. H., Koh, F. C., Chiou, K. Y. H., \& Phelps, S. J. 
(2005). Exercise Performance While Wearing a Tight-Fitting Powered Air Purifying Respirator with Limited Flow. Journal of Occupational and Environmental Hygiene, 2(7), 368-373. https://doi.org/10.1080/15459620591005044

11. KHOO, K.-L., LENG, P.-H., IBRAHIM, I. B., \& LIM, T. (2005). The changing face of healthcare worker perceptions on powered air-purifying respirators during the SARS outbreak. Respirology, 10(1), 107-110. https://doi.org/10.1111/j.14401843.2005.00634.x

12. Kim, J.-H., Benson, S. M., \& Roberge, R. J. (2013). Pulmonary and heart rate responses to wearing N95 filtering facepiece respirators. American Journal of Infection Control, 4l(1), 24-27. https://doi.org/10.1016/j.ajic.2012.02.037

13. Kim, J.-H., Wu, T., Powell, J. B., \& Roberge, R. J. (2016). Physiologic and fit factor profiles of N95 and P100 filtering facepiece respirators for use in hot, humid environments. American Journal of Infection Control, 44(2), 194-198. https://doi.org/10.1016/j.ajic.2015.08.027

14. Koivisto, A. J., Aromaa, M., Koponen, I. K., Fransman, W., Jensen, K. A., Mäkelä, J. M., \& Hämeri, K. J. (2015). Workplace performance of a loose-fitting powered air purifying respirator during nanoparticle synthesis. Journal of Nanoparticle Research, 17(4), 177. https://doi.org/10.1007/s11051-015-2990-9

15. LaVela, S. L., Kostovich, C., Locatelli, S., Gosch, M., Eagan, A., \& Radonovich, L. (2017). Development and initial validation of the Respirator Comfort, Wearing Experience, and Function Instrument [R-COMFI]. Journal of Occupational and Environmental Hygiene, 14(2), 135-147. https://doi.org/10.1080/15459624.2016.1237025

16. Lim, E. C. H., Seet, R. C. S., Lee, K.-H., Wilder-Smith, E. P. V., Chuah, B. Y. S., \& Ong, B. K. C. (2006). Headaches and the N95 face-mask amongst healthcare providers. Acta Neurologica Scandinavica, 113(3), 199-202. https://doi.org/10.1111/j.16000404.2005.00560.x

17. Liverman, C. T., Domnitz, S. B., McCoy, M. A., Institute of Medicine (U.S.). Board on Health Sciences Policy, \& Use and Effectiveness of Powered Air Purifying Respirators in Health Care (Workshop) (2014 : Washington, D. C. . (n.d.). The use and effectiveness of powered air purifying respirators in health care : workshop summary.

18. Martin, S., Moyer, E., \& Jensen, P. (2006). Integrated Unit Performance Testing of Powered, Air-Purifying Particulate Respirators Using a DOP Challenge Aerosol. Journal of Occupational and Environmental Hygiene, 3(11), 631-641. https://doi.org/10.1080/15459620600954365

19. MYERS, W. R., PEACH, M. J., CUTRIGHT, K., \& ISKANDER, W. (1984). Workplace Protection Factor Measurements on Powered Air-Purifying Respirators at a Secondary 
Lead Smelter: Results and Discussion. AIHA Journal, 45(10), 681-688.

https://doi.org/10.1080/15298668491400449

20. Palmiero, A. J., Symons, D., Morgan, J. W., \& Shaffer, R. E. (2016). Speech

intelligibility assessment of protective facemasks and air-purifying respirators. Journal of Occupational and Environmental Hygiene, 13(12), 960-968.

https://doi.org/10.1080/15459624.2016.1200723

21. Powell, J. B., Kim, J.-H., \& Roberge, R. J. (2017). Powered air-purifying respirator use in healthcare: effects on thermal sensations and comfort. Journal of Occupational and Environmental Hygiene, 947-954. https://doi.org/10.1080/15459624.2017.1358817

22. Powered air-purifying respirators. (1995). Occupational Health \& Safety, 64(11).

23. Radonovich, L. J., Cheng, J., Shenal, B. V, Hodgson, M., \& Bender, B. S. (2009). Respirator Tolerance in Health Care Workers. JAMA, 301(1), 36. https://doi.org/10.1001/jama.2008.894

24. Radonovich, L. J., Yanke, R., Cheng, J., \& Bender, B. (2009). Diminished Speech Intelligibility Associated with Certain Types of Respirators Worn by Healthcare Workers. Journal of Occupational and Environmental Hygiene, 7(1), 63-70. https://doi.org/10.1080/15459620903404803

25. Respiratory Protection. - 1910.134 | Occupational Safety and Health Administration. (1998). Retrieved August 25, 2017, from

https://www.osha.gov/pls/oshaweb/owadisp.show_document?p_table=standards\&p_id=1 2716

26. Roberge, R., Benson, S., \& Kim, J.-H. (2012). Thermal Burden of N95 Filtering Facepiece Respirators. The Annals of Occupational Hygiene, 56(7), 808-14. https://doi.org/10.1093/annhyg/mes001

27. Roberge, R. J., Bayer, E., Powell, J. B., Coca, A., Roberge, M. R., \& Benson, S. M. (2010). Effect of Exhaled Moisture on Breathing Resistance of N95 Filtering Facepiece Respirators. The Annals of Occupational Hygiene, 54(6), 671-7. https://doi.org/10.1093/annhyg/meq042

28. Roberge, R. J., Coca, A., Williams, W. J., Powell, J. B., \& Palmiero, A. J. (2010). Physiological impact of the N95 filtering facepiece respirator on healthcare workers. Respiratory Care, 55(5), 569-77.

29. Roberge, R. J., Kim, J.-H., \& Benson, S. (2012). N95 Filtering Facepiece Respirator Deadspace Temperature and Humidity. Journal of Occupational and Environmental Hygiene, 9(3), 166-171. https://doi.org/10.1080/15459624.2012.660428

30. Roberge, R. J., Kim, J.-H., \& Powell, J. B. (2014). N95 respirator use during advanced 
pregnancy. American Journal of Infection Control, 42(10), 1097-1100.

https://doi.org/10.1016/j.ajic.2014.06.025

31. Shenal, B. V., Radonovich, L. J., Cheng, J., Hodgson, M., \& Bender, B. S. (2012). Discomfort and Exertion Associated with Prolonged Wear of Respiratory Protection in a Health Care Setting. Journal of Occupational and Environmental Hygiene, 9(1), 59-64. https://doi.org/10.1080/15459624.2012.635133

32. TB Respiratory Protection Program In Health Care Facilities Administrator's Guide. (1999). Retrieved September 5, 2017, from https://www.cdc.gov/niosh/docs/99143/pdfs/99-143.pdf

33. Zamora, J. E., Murdoch, J., Simchison, B., \& Day, A. G. (2006). Contamination: a comparison of 2 personal protective systems. CMAJ: Canadian Medical Association Journal = Journal de l'Association Medicale Canadienne, 175(3), 249-54. https://doi.org/10.1503/cmaj.060094 


\section{Appendix A: Screening Questionnaire Sample Assessing acceptability and perceived protective efficiency of PAPRs}

\begin{tabular}{|c|c|c|c|}
\hline \multicolumn{4}{|c|}{ PLEASE PRINT AND COMPLETE ALL ENTRIES } \\
\hline \multicolumn{3}{|c|}{ NAME (LAST -- FIRST -- MIDDLE INITIAL) } & JOB TITLE \\
\hline SEX (M or F) & Phone Number & Email Address & YEARS OF WORK EXPERIENCE \\
\hline \multicolumn{2}{|c|}{$\begin{array}{l}\text { Have you used a PAPR before? (Yes or } \\
\text { No) }\end{array}$} & \multicolumn{2}{|c|}{$\begin{array}{l}\text { If you have used a PAPR before, what specific activities do you use it } \\
\text { for? }\end{array}$} \\
\hline \multicolumn{4}{|c|}{ Which hospital unit/department are you from? Please briefly describe your daily work activities. } \\
\hline \multicolumn{4}{|c|}{$\begin{array}{l}\text { What is your experience with the following activities? (1: very experienced, 2: somewhat experienced; } 3 \text { : } \\
\text { inexperienced) }\end{array}$} \\
\hline \multicolumn{4}{|c|}{ Set up bedding/room } \\
\hline \multicolumn{4}{|c|}{ Position patient } \\
\hline \multicolumn{2}{|c|}{ Assess patient } & & \\
\hline \multicolumn{4}{|c|}{ Hook up monitoring devices } \\
\hline \multicolumn{4}{|c|}{ Insert IV } \\
\hline \multicolumn{4}{|c|}{ Draw blood } \\
\hline \multicolumn{4}{|c|}{ Start IV equipment } \\
\hline \multicolumn{4}{|c|}{ Insert and set up foley } \\
\hline \multicolumn{4}{|c|}{ Take urine sample } \\
\hline \multicolumn{4}{|c|}{ Turn and bathe patient } \\
\hline \multicolumn{2}{|c|}{ Suctioning } & & \\
\hline & orm CPR & & \\
\hline
\end{tabular}




\section{Appendix B: PAPR Questionnaire Sample}

\section{Assessing user discomfort, acceptability and perceived protective efficiency of PAPRs in healthcare work settings}

Date:

Study ID:

BASIC INFOMATION

\begin{tabular}{|c|c|c|c|c|}
\hline \multicolumn{3}{|c|}{ NAME (LAST -- FIRST -- MIDDLE INITIAL) } & \multicolumn{2}{|l|}{ JOB TITLE } \\
\hline $\begin{array}{l}\text { SEX } \\
\text { a Male a Female }\end{array}$ & AGE (Years) & Weight (lb.) & Have you used PAPRs? & YEARS OF WORK EXPERIENCE \\
\hline
\end{tabular}

List of Tested Respirators:

\begin{tabular}{|l|l|l|l|l|}
\hline & & & & \\
\hline & & MAX AIR & Versflow & AIR MATE \\
\hline $\begin{array}{l}\text { Time } \\
\text { Start: } \\
\text { Time } \\
\text { Stop: }\end{array}$ & & & & \\
\hline
\end{tabular}

Note: The order of the three PAPRs was completely randomized for each subject test. 


\begin{tabular}{|c|}
\hline List of Exercises \\
\hline Set up bedding/room \\
\hline Position patient \\
\hline Assess patient \\
\hline Hook up monitoring devices \\
\hline Insert IV \\
\hline Draw blood \\
\hline Start IV equipment \\
\hline Insert and set up foley \\
\hline Take urine sample \\
\hline Turn and bathe patient \\
\hline Suctioning \\
\hline Perform CPR \\
\hline
\end{tabular}


Study ID:

Place a circle next to the following scales corresponding to your evaluation of each respirator.

\begin{tabular}{|c|c|c|c|c|c|c|c|c|c|}
\hline \multicolumn{10}{|c|}{ General comfort } \\
\hline \multicolumn{2}{|c|}{ Respirator 1} & \multicolumn{2}{|c|}{ Respirator 2} & \multicolumn{2}{|c|}{ Respirator 3} & \multicolumn{2}{|c|}{ Respirator 4} & \multicolumn{2}{|c|}{ Respirator 5} \\
\hline $\begin{array}{l}\text { Very poor } \\
1\end{array}$ & $T$ & $\begin{array}{l}\text { Very poor } \\
1\end{array}$ & $\mathrm{~T}$ & $\begin{array}{l}\text { Very poor } \\
1\end{array}$ & $\mathrm{~T}$ & $\begin{array}{l}\text { Very poor } \\
1\end{array}$ & $T$ & $\begin{array}{l}\text { Very poor } \\
1\end{array}$ & \\
\hline Poor & + & Poor & + & Poor & + & Poor & - & Poor & $t$ \\
\hline 2 & & 2 & & 2 & & 2 & & 2 & \\
\hline Acceptable & $t$ & Acceptable & $t$ & Acceptable & + & Acceptable & $t$ & Acceptable & \\
\hline 3 & & 3 & & 3 & & 3 & & 3 & \\
\hline $\begin{array}{l}\text { Good } \\
4\end{array}$ & $t$ & $\begin{array}{l}\text { Good } \\
4\end{array}$ & $t$ & $\begin{array}{l}\text { Good } \\
4\end{array}$ & $t$ & $\begin{array}{l}\text { Good } \\
4\end{array}$ & t & $\begin{array}{l}\text { Good } \\
4\end{array}$ & $t$ \\
\hline $\begin{array}{l}\text { Very good } \\
5\end{array}$ & - & $\begin{array}{l}\text { Very good } \\
5\end{array}$ & - & $\begin{array}{l}\text { Very good } \\
5\end{array}$ & - & $\begin{array}{l}\text { Very good } \\
5\end{array}$ & - & $\begin{array}{l}\text { Very good } \\
5\end{array}$ & - \\
\hline $\begin{array}{l}\text { Excellent } \\
6\end{array}$ & - & $\begin{array}{l}\text { Excellent } \\
6\end{array}$ & - & $\begin{array}{l}\text { Excellent } \\
6\end{array}$ & - & $\begin{array}{l}\text { Excellent } \\
6\end{array}$ & - & $\begin{array}{l}\text { Excellent } \\
6\end{array}$ & - \\
\hline
\end{tabular}

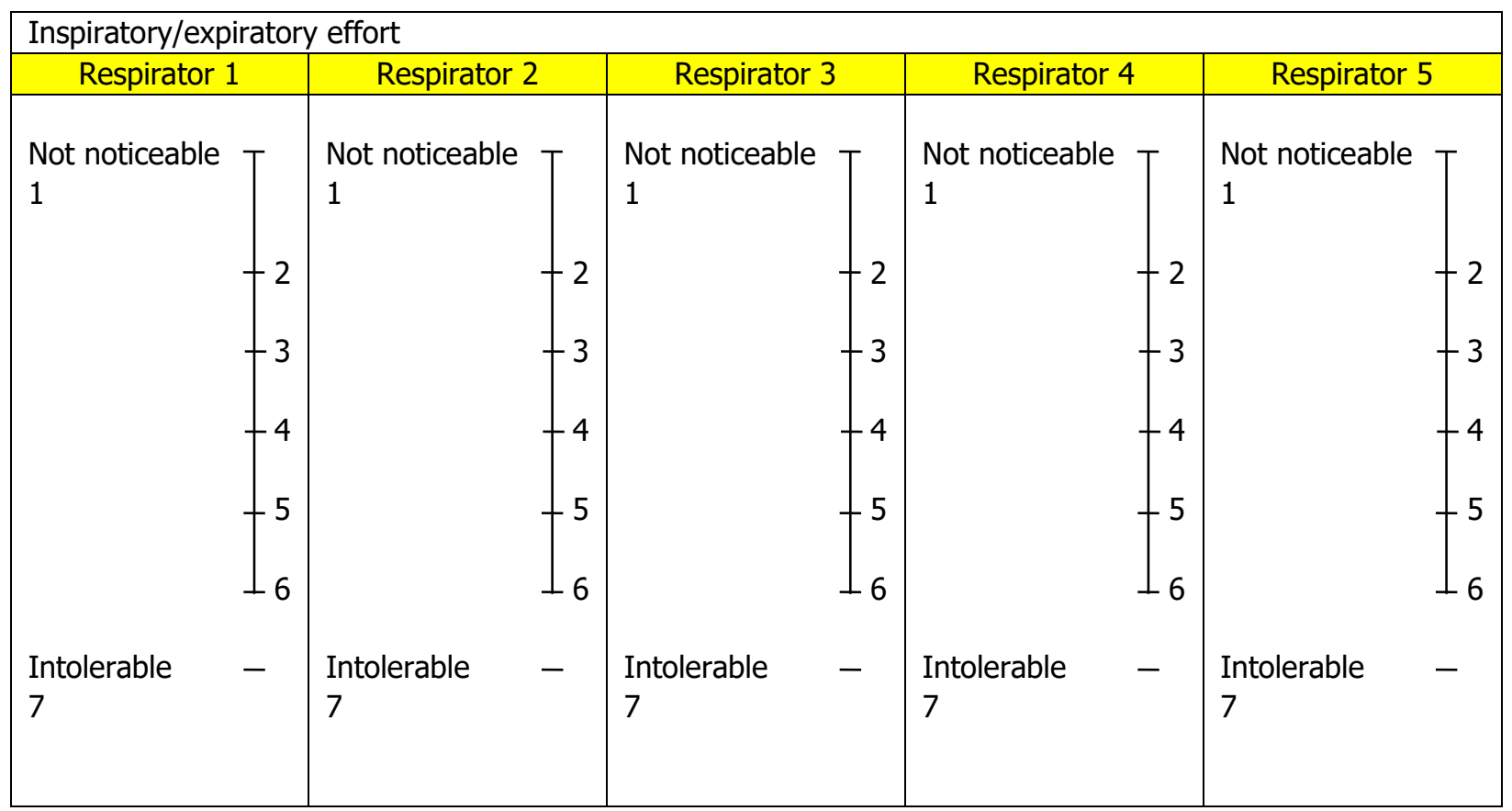




\begin{tabular}{|c|c|c|c|c|c|c|c|c|}
\hline \multicolumn{9}{|c|}{ Overall breathing discomfort } \\
\hline Respirator 1 & \multicolumn{2}{|l|}{ Respirator 2} & \multicolumn{2}{|l|}{ Respirator 3} & \multicolumn{2}{|l|}{ Respirator 4} & \multicolumn{2}{|c|}{ Respirator 5} \\
\hline Not at all & Not at all & $T^{1}$ & Not at all & $T^{1}$ & Not at all & $T^{1}$ & Not at all & $\mathrm{T}^{1}$ \\
\hline Very slight & Very slight & -2 & Very slight & -2 & Very slight & -2 & Very slight & -2 \\
\hline Slight & Slight & -3 & Slight & -3 & Slight & -3 & Slight & +3 \\
\hline Somewhat high -4 & Somewhat high & -4 & Somewhat high & -4 & Somewhat high & -4 & Somewhat high & -4 \\
\hline High & High & $t$ & High & + & High & + & High & $t$ \\
\hline 5 & 5 & 1 & 5 & | & 5 & 1 & 5 & 1 \\
\hline Unbearable & Unbearable & -6 & Unbearable & -6 & Unbearable & -6 & Unbearable & -6 \\
\hline
\end{tabular}


Study ID:

\begin{tabular}{|c|c|c|c|c|c|c|c|c|}
\hline \multicolumn{9}{|l|}{ Facial and body heat } \\
\hline Respirator 1 & \multicolumn{2}{|l|}{ Respirator 2} & \multicolumn{2}{|l|}{ Respirator 3} & \multicolumn{2}{|l|}{ Respirator 4} & \multicolumn{2}{|l|}{ Respirator 5} \\
\hline Not at all & Not at all & $T^{1}$ & Not at all & $\mathrm{T}^{1}$ & Not at all & $T^{1}$ & Not at all & $T^{1}$ \\
\hline Very slight & Very slight & -2 & Very slight & -2 & Very slight & -2 & Very slight & -2 \\
\hline Slight & Slight & -3 & Slight & -3 & Slight & -3 & Slight & -3 \\
\hline Somewhat high -4 & Somewhat high & -4 & Somewhat high & -4 & Somewhat high & -4 & Somewhat high & -4 \\
\hline High & High & + & High & $t$ & High & + & High & + \\
\hline 5 & 5 & | & 5 & 1 & 5 & $\mid$ & 5 & | \\
\hline Unbearable & Unbearable & -6 & Unbearable & -6 & Unbearable & -6 & Unbearable & -6 \\
\hline
\end{tabular}

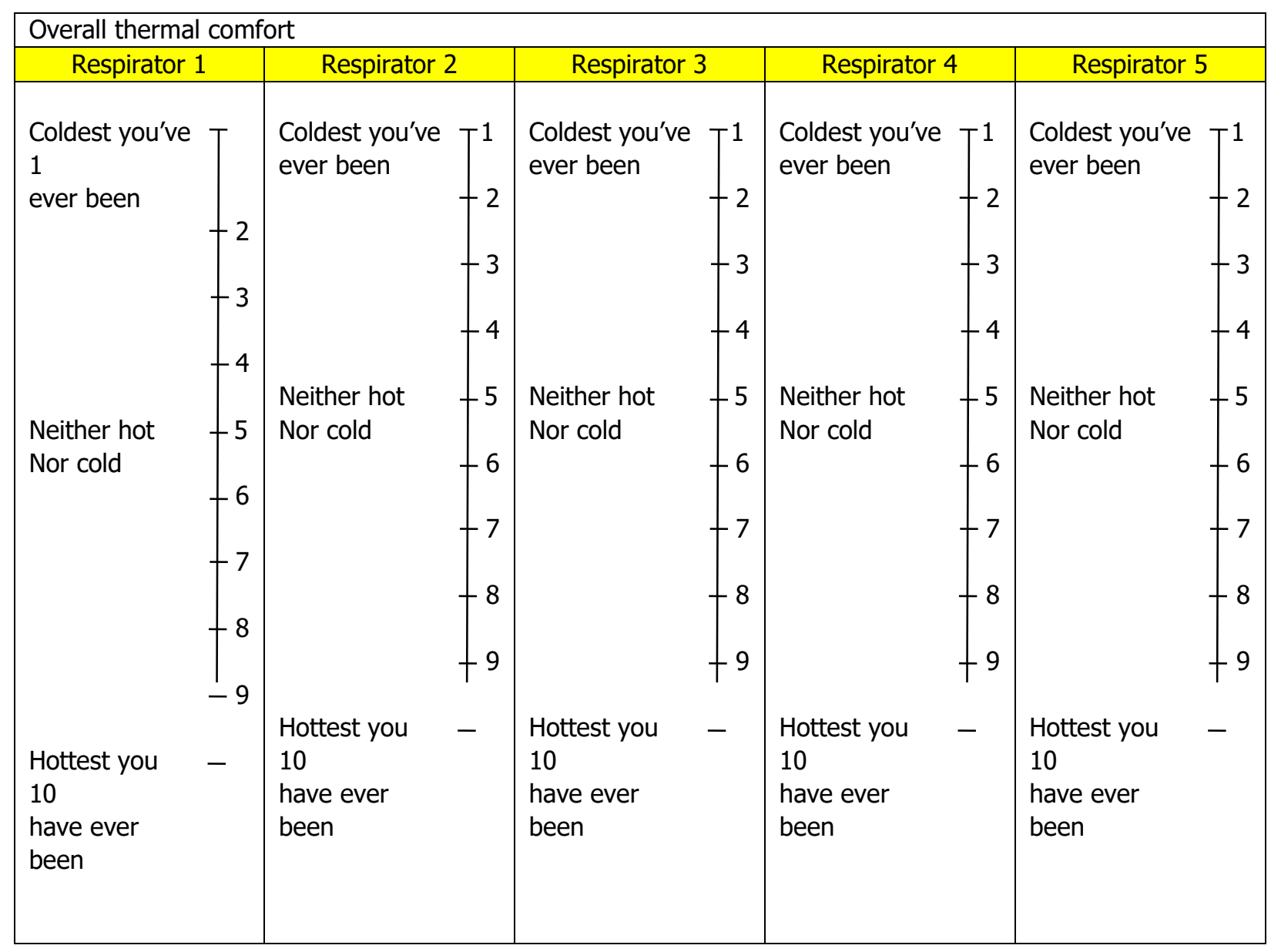


Study ID:

\begin{tabular}{|c|c|c|c|c|c|c|c|c|}
\hline \multicolumn{9}{|l|}{ Pressure or pain } \\
\hline Respirator 1 & \multicolumn{2}{|l|}{ Respirator 2} & \multicolumn{2}{|l|}{ Respirator 3} & \multicolumn{2}{|l|}{ Respirator 4} & \multicolumn{2}{|l|}{ Respirator 5} \\
\hline Not at all & Not at all & $\mathrm{T}^{1}$ & Not at all & $\mathrm{T}^{1}$ & Not at all & $\top^{1}$ & Not at all & $\mathrm{T}^{1}$ \\
\hline Very slight & Very slight & -2 & Very slight & -2 & Very slight & -2 & Very slight & -2 \\
\hline Slight & Slight & +3 & Slight & -3 & Slight & -3 & Slight & -3 \\
\hline Somewhat high -4 & Somewhat high & -4 & Somewhat high & -4 & Somewhat high & -4 & Somewhat high & -4 \\
\hline High & High & f & High & 1 & High & + & High & + \\
\hline 5 & 5 & | & 5 & | & 5 & $\mid$ & 5 & | \\
\hline Unbearable & Unbearable & -6 & Unbearable & -6 & Unbearable & -6 & Unbearable & -6 \\
\hline
\end{tabular}

\begin{tabular}{|c|c|c|c|c|c|c|c|c|c|}
\hline \multicolumn{10}{|l|}{ Eye discomfort } \\
\hline \multicolumn{2}{|l|}{ Respirator 1} & \multicolumn{2}{|l|}{ Respirator 2} & \multicolumn{2}{|l|}{ Respirator 3} & \multicolumn{2}{|l|}{ Respirator 4} & \multicolumn{2}{|l|}{ Respirator 5} \\
\hline Not at all & $T^{1}$ & Not at all & $\mathrm{T}^{1}$ & Not at all & $T^{1}$ & Not at all & $T^{1}$ & Not at all & $T^{1}$ \\
\hline Very slight & -2 & Very slight & +2 & Very slight & +2 & Very slight & -2 & Very slight & -2 \\
\hline Slight & -3 & Slight & -3 & Slight & -3 & Slight & -3 & Slight & -3 \\
\hline Somewhat high & -4 & Somewhat high & -4 & Somewhat high & -4 & Somewhat high & -4 & Somewhat high & -4 \\
\hline High & -5 & High & -5 & High & -5 & $\begin{array}{l}\text { High } \\
5\end{array}$ & + & $\begin{array}{l}\text { High } \\
5\end{array}$ & t \\
\hline Unbearable & -6 & Unbearable & -6 & Unbearable & -6 & & & & \\
\hline & & & & & & Unbearable & -6 & Unbearable & -6 \\
\hline
\end{tabular}




\begin{tabular}{|c|c|c|c|c|c|c|c|c|}
\hline \multicolumn{9}{|c|}{$\begin{array}{l}\text { Interference with wearing glasses/goggles/contact lenses (Don't complete the section if you don't } \\
\text { wear one of those) }\end{array}$} \\
\hline Respirator 1 & \multicolumn{2}{|c|}{ Respirator 2} & \multicolumn{2}{|c|}{ Respirator 3} & \multicolumn{2}{|c|}{ Respirator 4} & \multicolumn{2}{|l|}{ Respirator 5} \\
\hline Not at all & Not at all & $T^{1}$ & Not at all & $T^{1}$ & Not at all & $T^{1}$ & Not at all & $T^{1}$ \\
\hline Very slight & Very slight & -2 & Very slight & -2 & Very slight & -2 & Very slight & -2 \\
\hline Slight & Slight & -3 & Slight & -3 & Slight & -3 & Slight & +3 \\
\hline Somewhat high -4 & Somewhat high & -4 & Somewhat high & -4 & Somewhat high & -4 & Somewhat high & -4 \\
\hline High & High & $t$ & High & + & High & + & High & + \\
\hline 5 & 5 & $\mid$ & 5 & | & 5 & 1 & 5 & | \\
\hline Unbearable & Unbearable & -6 & Unbearable & -6 & Unbearable & -6 & Unbearable & -6 \\
\hline
\end{tabular}


Study ID:

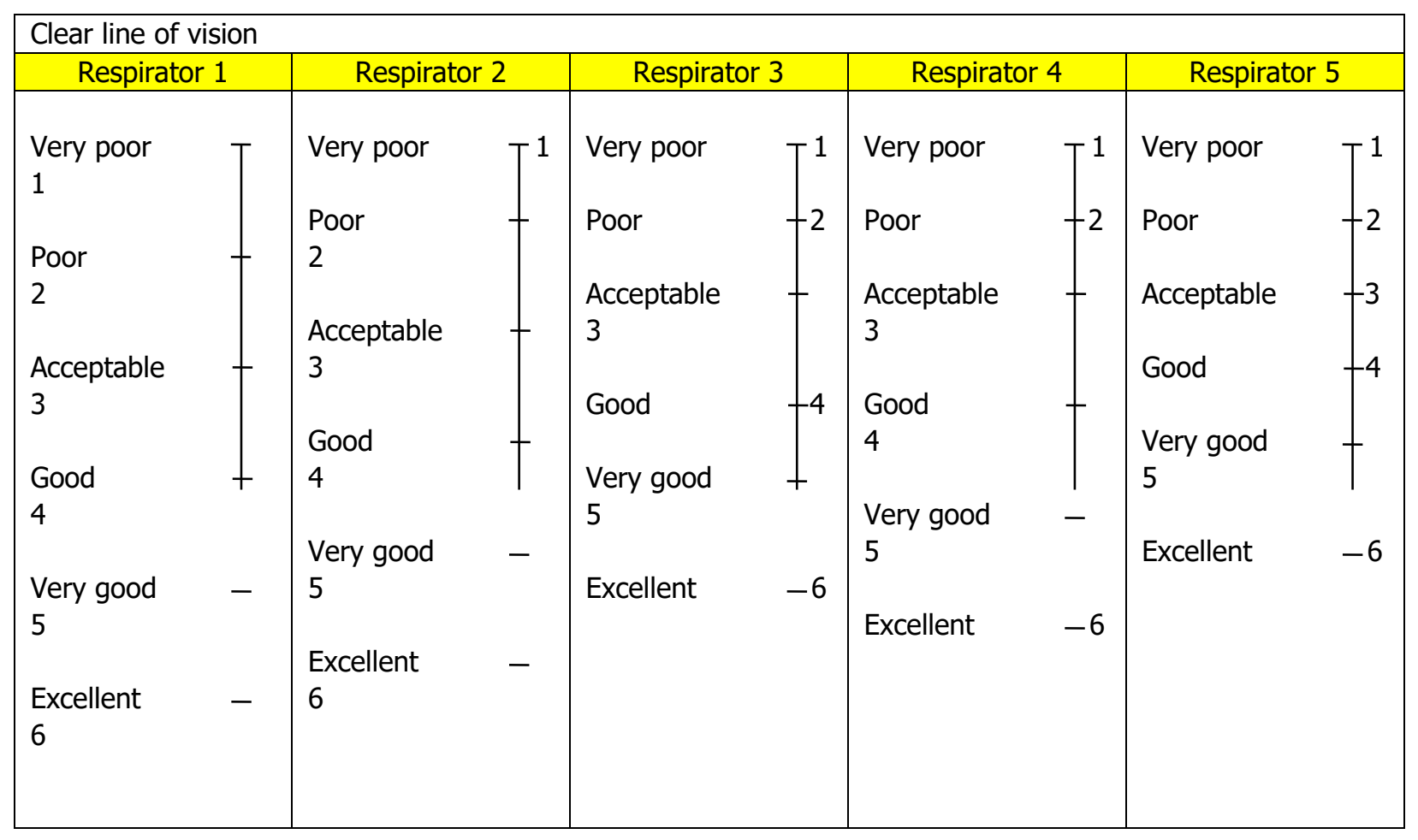

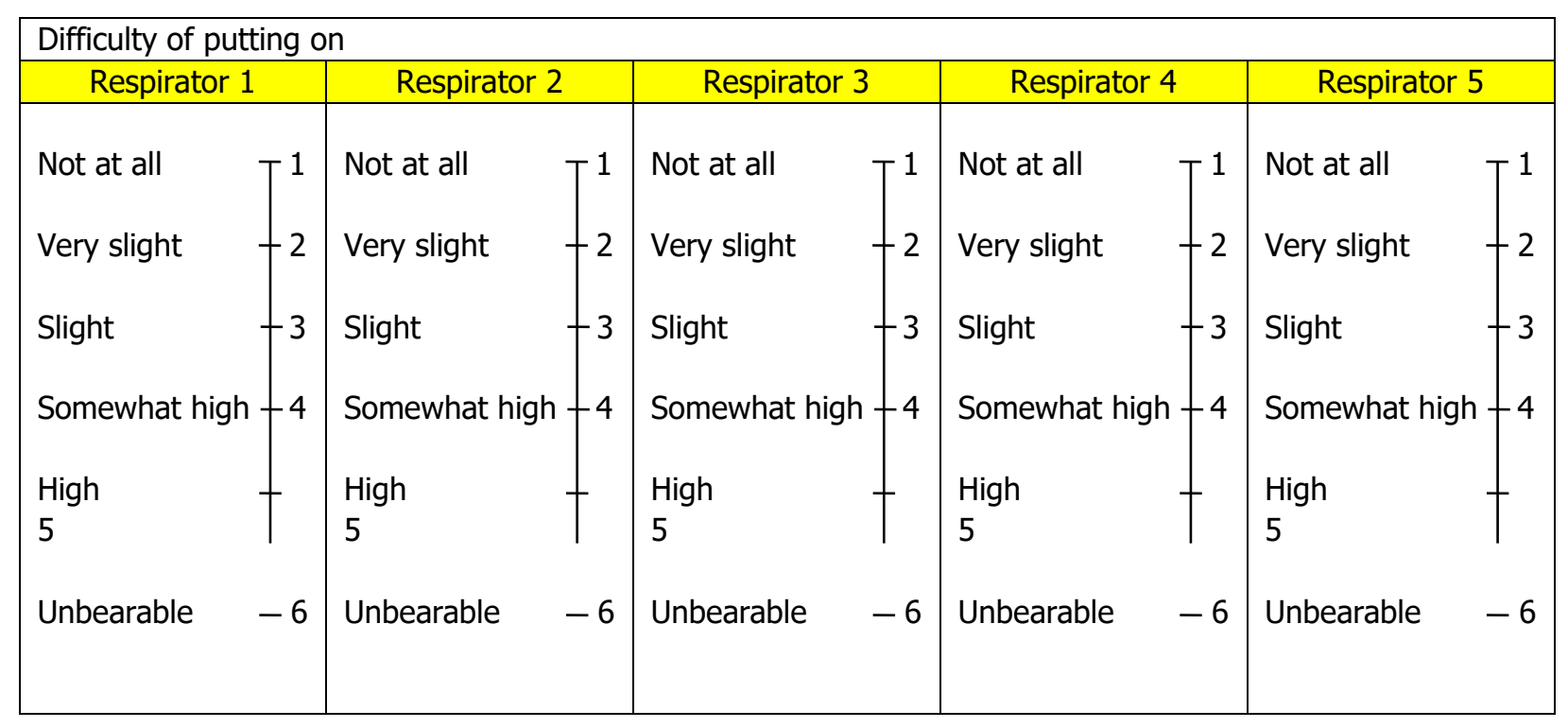


Study ID:

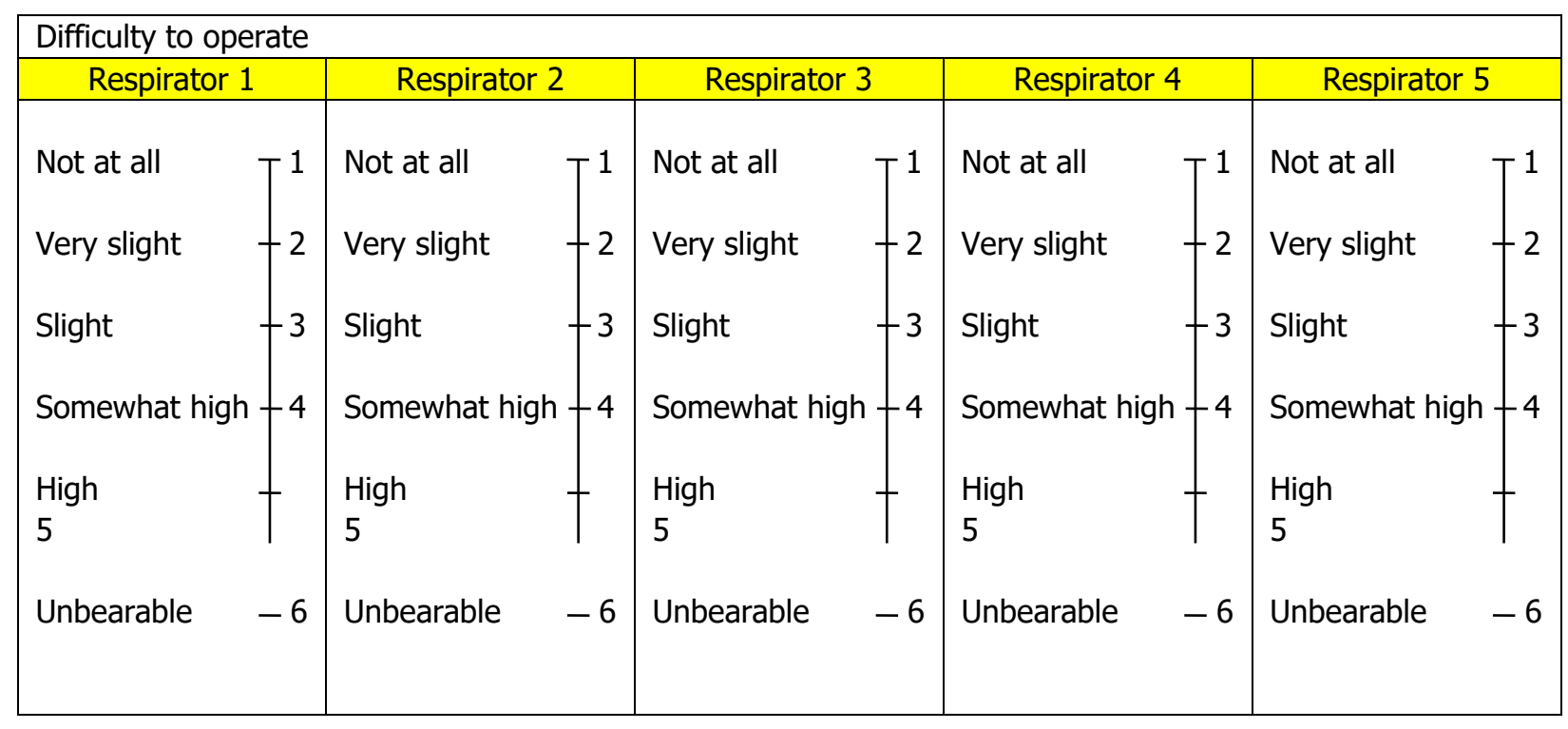

\begin{tabular}{|c|c|c|c|c|c|c|c|c|}
\hline \multicolumn{9}{|c|}{ Mechanical interference with duties } \\
\hline Respirator 1 & \multicolumn{2}{|l|}{ Respirator 2} & \multicolumn{2}{|l|}{ Respirator 3} & \multicolumn{2}{|l|}{ Respirator 4} & \multicolumn{2}{|l|}{ Respirator 5} \\
\hline Not at all & Not at all & $T^{1}$ & Not at all & $T^{1}$ & Not at all & $T^{1}$ & Not at all & $T^{1}$ \\
\hline Very slight & Very slight & -2 & Very slight & -2 & Very slight & -2 & Very slight & -2 \\
\hline Slight & Slight & -3 & Slight & -3 & Slight & -3 & Slight & -3 \\
\hline Somewhat high -4 & Somewhat high & -4 & Somewhat high & -4 & Somewhat high & -4 & Somewhat high & -4 \\
\hline High & High & $\theta$ & High & $f$ & High & + & High & $t$ \\
\hline 5 & 5 & | & 5 & 1 & 5 & | & 5 & | \\
\hline Unbearable & Unbearable & -6 & Unbearable & -6 & Unbearable & -6 & Unbearable & -6 \\
\hline
\end{tabular}


Study ID:

\begin{tabular}{|c|c|c|c|c|c|c|c|c|c|}
\hline \multicolumn{10}{|l|}{ Exertion } \\
\hline \multicolumn{2}{|c|}{ Respirator 1} & \multicolumn{2}{|c|}{ Respirator 2} & \multicolumn{2}{|c|}{ Respirator 3} & \multicolumn{2}{|c|}{ Respirator 4} & \multicolumn{2}{|c|}{ Respirator 5} \\
\hline $\begin{array}{l}\text { No exertion } \\
6 \\
\text { at all }\end{array}$ & $T_{7}$ & $\begin{array}{l}\text { No exertion } \\
6 \\
\text { at all }\end{array}$ & $T_{7}$ & $\begin{array}{l}\text { No exertion } \\
6 \\
\text { at all }\end{array}$ & $T_{7}$ & $\begin{array}{l}\text { No exertion } \\
6 \\
\text { at all }\end{array}$ & $T_{7}$ & $\begin{array}{l}\text { No exertion } \\
6 \\
\text { at all }\end{array}$ & $T_{7}$ \\
\hline 10 & & 10 & & 10 & 1 & 10 & 1 & 10 & \\
\hline 11 & & 11 & & 11 & 1 & 11 & 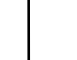 & 11 & 1 \\
\hline 12 & & 12 & & 12 & 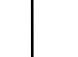 & 12 & 1 & 12 & \\
\hline 13 & & 13 & & 13 & 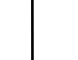 & 13 & 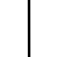 & 13 & | \\
\hline 14 & & 14 & 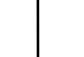 & 14 & 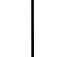 & 14 & 1 & 14 & \\
\hline 15 & & 15 & & 15 & 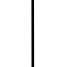 & 15 & & 15 & \\
\hline 16 & - & 16 & - & 16 & - & 16 & - & 16 & - \\
\hline 17 & - & 17 & - & 17 & - & 17 & - & 17 & - \\
\hline 18 & - & 18 & - & 18 & - & 18 & - & 18 & - \\
\hline 19 & - & 19 & - & 19 & - & 19 & - & 19 & - \\
\hline $\begin{array}{l}\text { Maximal } \\
20 \\
\text { exertion }\end{array}$ & - & $\begin{array}{l}\text { Maximal } \\
20 \\
\text { exertion }\end{array}$ & - & $\begin{array}{l}\text { Maximal } \\
20 \\
\text { exertion }\end{array}$ & - & $\begin{array}{l}\text { Maximal } \\
20 \\
\text { exertion }\end{array}$ & - & $\begin{array}{l}\text { Maximal } \\
20 \\
\text { exertion }\end{array}$ & - \\
\hline
\end{tabular}




\begin{tabular}{|c|c|c|c|c|}
\hline How many hours do you think you could wear this respirator continuously? \\
\hline Respirator 1 & Respirator 2 & Respirator 3 & Respirator 4 & Respirator 5 \\
\hline & & & & \\
\hline
\end{tabular}

\begin{tabular}{|c|c|c|c|c|c|c|c|c|}
\hline \multicolumn{9}{|c|}{ Perceived efficiency against biological hazards } \\
\hline Respirator 1 & \multicolumn{2}{|c|}{ Respirator 2} & \multicolumn{2}{|l|}{ Respirator 3} & \multicolumn{2}{|l|}{ Respirator 4} & \multicolumn{2}{|l|}{ Respirator 5} \\
\hline Not at all & Not at all & $\mathrm{T}^{1}$ & Not at all & $\mathrm{T}^{1}$ & Not at all & $T^{1}$ & Not at all & $T^{1}$ \\
\hline Very slight & Very slight & -2 & Very slight & -2 & Very slight & -2 & Very slight & -2 \\
\hline Slight & Slight & -3 & Slight & -3 & Slight & -3 & Slight & -3 \\
\hline Somewhat high -4 & Somewhat high & -4 & Somewhat high & -4 & Somewhat high & -4 & Somewhat high & -4 \\
\hline High & High & 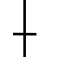 & High & ] & High & - & High & + \\
\hline 5 & 5 & T & 5 & 1 & 5 & $\mid$ & 5 & 1 \\
\hline Complete & Complete & -6 & Complete & -6 & Complete & -6 & Complete & -6 \\
\hline
\end{tabular}

Study ID:

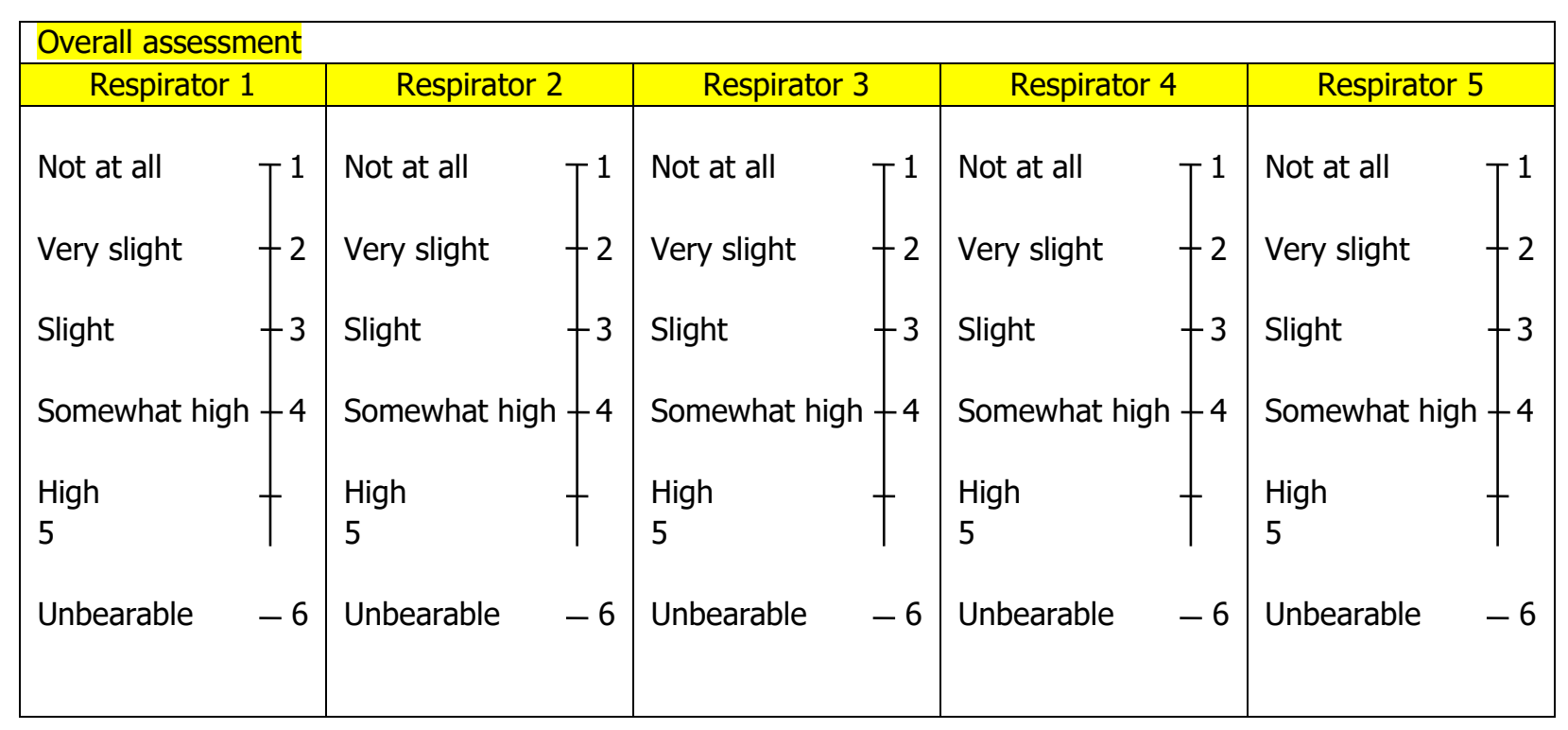




\begin{tabular}{|c|c|c|c|c|}
\hline \multirow{2}{*}{$\begin{array}{l}\text { RESPIRATOR } \\
\text { TYPE }\end{array}$} & \multicolumn{3}{|c|}{ VITAL SIGNS } & \multirow{2}{*}{$\begin{array}{c}\text { EXPERIENCE OF USING ANY TYPE OF } \\
\text { RESPIRATOR BEFORE }\end{array}$} \\
\hline & $\begin{array}{l}\text { Heart Rate } \\
(/ \mathrm{mins})\end{array}$ & $\begin{array}{l}\text { Respiratory } \\
\text { Rate(/mins) }\end{array}$ & $\begin{array}{l}\mathrm{SpO2} \\
(\%)\end{array}$ & \\
\hline \multicolumn{5}{|l|}{ Respirator 1} \\
\hline \multicolumn{5}{|l|}{ Respirator 2} \\
\hline \multicolumn{5}{|l|}{ Respirator 3} \\
\hline \multicolumn{5}{|l|}{ Respirator 4} \\
\hline Respirator 5 & & & & \\
\hline
\end{tabular}

AFTER TEST
\begin{tabular}{|l|l|l|l|l|}
\hline \multirow{2}{*}{ RESPIRATOR TYPE } & \multicolumn{3}{|c|}{ VITAL SIGNS } & \multirow{2}{*}{$\begin{array}{c}\text { SPEECH INTELLIGIBILITY TEST } \\
\text { (MRT) }\end{array}$} \\
\cline { 2 - 5 } & $\begin{array}{l}\text { Heart Rate } \\
\text { (/mins) }\end{array}$ & $\begin{array}{l}\text { Respiratory } \\
\text { Rate(/mins) }\end{array}$ & SpO2 (\%) \\
\hline Respirator 1 & & & & \\
\hline Respirator 2 & & & & \\
\hline Respirator 3 & & & & \\
\hline Respirator 4 & & & & \\
\hline Respirator 5 & & & & \\
\hline
\end{tabular}




\section{Study ID:}

\section{QUESTIONNAIRE SURVEY}

\begin{tabular}{|c|c|c|c|c|}
\hline \multicolumn{5}{|c|}{ Evaluation on preference and acceptability comparing low flow rate with high flow rate for low-risk tasks } \\
\hline Questions & & $\begin{array}{l}\text { MAX } \\
\text { AIR }\end{array}$ & Versflow & $\begin{array}{c}\text { AIR } \\
\text { MATE }\end{array}$ \\
\hline $\begin{array}{l}\text { When performing the following tasks (deemed low risks), do you prefer a } \\
\text { lower flow rate for the following PAPR? (yes and no for each PAPR model) }\end{array}$ & $N / A$ & & & \\
\hline $\begin{array}{l}\text { When performing the following tasks (deemed low risks), do you think a } \\
\text { lower flow rate is more acceptable? (yes and no for each PAPR model) }\end{array}$ & $N / A$ & & & \\
\hline $\begin{array}{l}\text { When performing the following tasks (deemed low risks), do you think a } \\
\text { lower flow rate is more effective? (yes and no for each PAPR model) }\end{array}$ & $N / A$ & & & \\
\hline
\end{tabular}

\section{Other symptoms}

\begin{tabular}{|l|l|l|l|l|l|}
\hline $\begin{array}{l}\text { Somatic complaints for respirators } \\
\text { (Yes and No for each symptom) }\end{array}$ & $\begin{array}{l}\text { Respirator } \\
1\end{array}$ & Respirator 2 & Respirator 3 & $\begin{array}{l}\text { Respirator } \\
4\end{array}$ & $\begin{array}{l}\text { Respirator } \\
5\end{array}$ \\
\hline Nausea & & & & & \\
\hline Dizziness or difficult concentrating & & & & & \\
\hline Unusual smell/odor & & & & & \\
\hline Eye irritation signs (if any) & & & & & \\
\hline
\end{tabular}

\section{OTHER COMMENTS:}




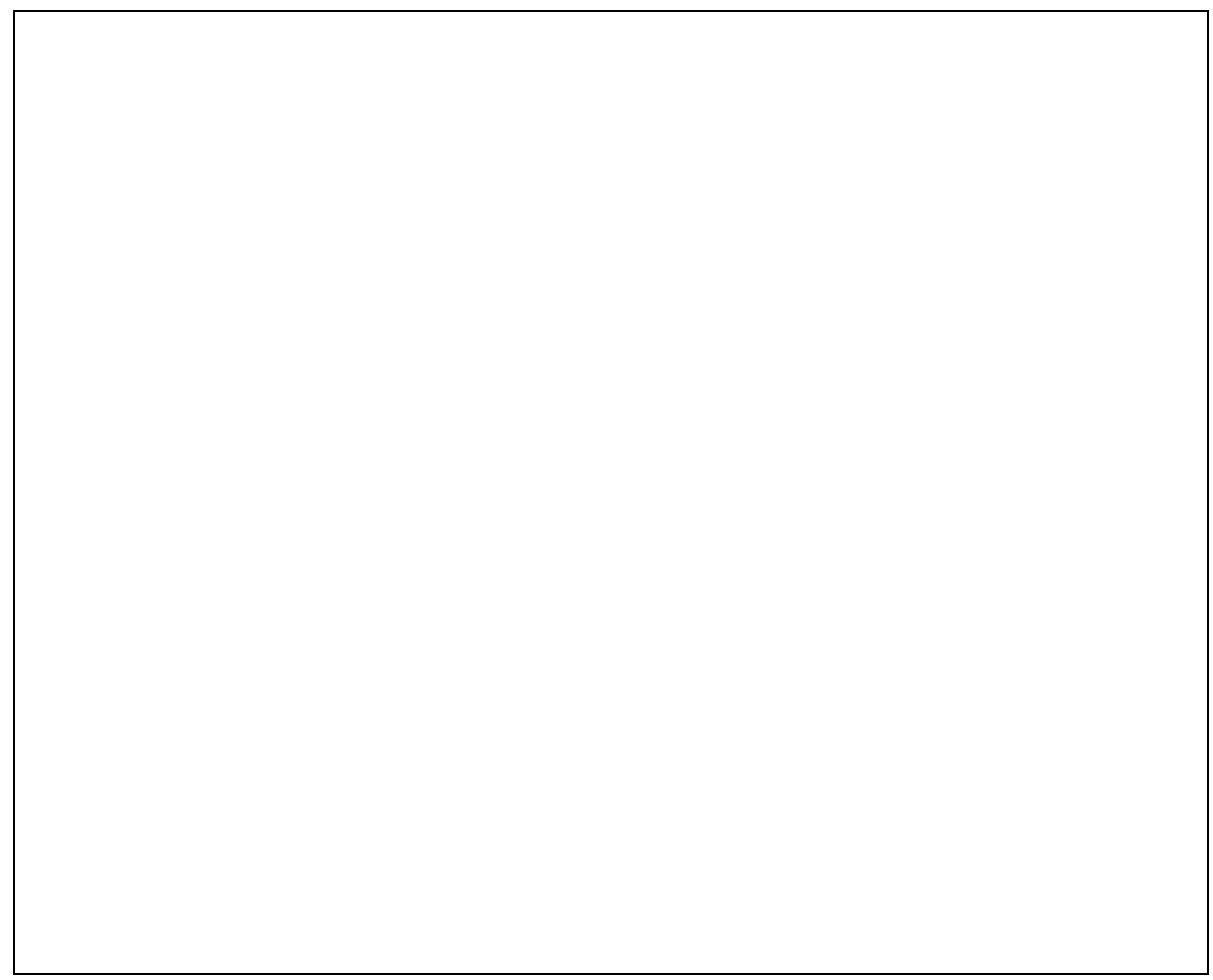




\section{Appendix C: Raw Data}

\section{C.1 Evaluation Categories}

\begin{tabular}{|c|c|c|c|c|c|c|c|c|}
\hline MAXAIR & $\begin{array}{l}\text { Subject } \\
001\end{array}$ & $\begin{array}{l}\text { Subject } \\
002\end{array}$ & $\begin{array}{l}\text { Subject } \\
003\end{array}$ & $\begin{array}{l}\text { Subject } \\
004\end{array}$ & $\begin{array}{l}\text { Subject } \\
005\end{array}$ & $\begin{array}{l}\text { Subject } \\
006\end{array}$ & $\begin{array}{l}\text { Subject } \\
007\end{array}$ & $\begin{array}{l}\text { Subject } \\
008\end{array}$ \\
\hline General comfort & 5 & 3 & 5 & 5 & 6 & 4 & 5 & 5 \\
\hline $\begin{array}{l}\text { Inspiratory/expir } \\
\text { atory effort }\end{array}$ & 1 & 1 & 2 & 2 & 1 & 1 & 2 & 1 \\
\hline $\begin{array}{l}\text { Overall } \\
\text { breathing } \\
\text { discomfort }\end{array}$ & 1 & 2 & 1 & 2 & 1 & 1 & 1 & 1 \\
\hline $\begin{array}{c}\text { Facial and body } \\
\text { heat }\end{array}$ & 2 & 2 & 3 & 2 & 1 & 2 & 2 & 1 \\
\hline $\begin{array}{l}\text { Overall thermal } \\
\text { comfort }\end{array}$ & 5 & 4 & 7 & 5 & 5 & 5 & 5 & 4 \\
\hline Pressure or pain & 3 & 1 & 1 & 1 & 1 & 2 & 1 & 1 \\
\hline Eye discomfort & 1 & 1 & 1 & 1 & 1 & 2 & 3 & 1 \\
\hline $\begin{array}{c}\text { Interference } \\
\text { with wearing } \\
\text { glasses/goggles/ } \\
\text { contacts }\end{array}$ & 1 & 2 & N/A & 1 & 1 & 1 & 2 & $\mathrm{~N} / \mathrm{A}$ \\
\hline $\begin{array}{c}\text { Clear line of } \\
\text { vision }\end{array}$ & 4 & 3 & 6 & 5 & 6 & 4 & 4 & 5 \\
\hline $\begin{array}{l}\text { Difficulty of } \\
\text { putting on }\end{array}$ & 4 & 3 & 3 & 2 & 1 & 2 & 2 & 3 \\
\hline $\begin{array}{l}\text { Difficulty to } \\
\text { operate }\end{array}$ & 3 & 3 & 1 & 2 & 1 & 2 & 2 & 1 \\
\hline $\begin{array}{c}\text { Mechanical } \\
\text { interference } \\
\text { with duties }\end{array}$ & 2 & 3 & 2 & 1 & 1 & 2 & 2 & 4 \\
\hline Exertion & 10 & 12 & 8 & 6 & 6 & 7 & 7 & 6 \\
\hline $\begin{array}{l}\text { How many hours } \\
\text { could you wear } \\
\text { this respirator } \\
\text { continuously? }\end{array}$ & 2 & 2 & 4 & 8 & 4 & 3 & 4 & 2 \\
\hline $\begin{array}{l}\text { Perceived } \\
\text { efficiency } \\
\text { against } \\
\text { biological } \\
\text { hazards }\end{array}$ & 4 & 4 & 6 & 5 & 5 & 3 & 3 & 3 \\
\hline $\begin{array}{c}\text { Overall } \\
\text { assessment }\end{array}$ & 3 & 3 & 2 & 2 & 1 & 2 & 2 & 1 \\
\hline
\end{tabular}




\begin{tabular}{|c|c|c|c|c|c|c|c|c|}
\hline Air-Mate & $\begin{array}{l}\text { Subject } \\
001\end{array}$ & $\begin{array}{l}\text { Subject } \\
002\end{array}$ & $\begin{array}{l}\text { Subject } \\
003\end{array}$ & $\begin{array}{l}\text { Subject } \\
004\end{array}$ & $\begin{array}{l}\text { Subject } \\
005\end{array}$ & $\begin{array}{l}\text { Subject } \\
006\end{array}$ & $\begin{array}{l}\text { Subject } \\
007\end{array}$ & $\begin{array}{l}\text { Subject } \\
008\end{array}$ \\
\hline General comfort & 3 & 4 & 4 & 3 & 4 & 3 & 5 & 5 \\
\hline $\begin{array}{l}\text { Inspiratory/expir } \\
\text { atory effort }\end{array}$ & 1 & 4 & 2 & 2 & 3 & 1 & 2 & 1 \\
\hline $\begin{array}{l}\text { Overall } \\
\text { breathing } \\
\text { discomfort }\end{array}$ & 1 & 3 & 2 & 2 & 2 & 1 & 2 & 1 \\
\hline $\begin{array}{c}\text { Facial and body } \\
\text { heat }\end{array}$ & 1 & 3 & 3 & 4 & 2 & 2 & 2 & 1 \\
\hline $\begin{array}{l}\text { Overall thermal } \\
\text { comfort }\end{array}$ & 5 & 5 & 5 & 7 & 5 & 5 & 5 & 4 \\
\hline Pressure or pain & 3 & 1 & 2 & 1 & 1 & 2 & 1 & 1 \\
\hline Eye discomfort & 1 & 1 & 2 & 1 & 1 & 2 & 1 & 1 \\
\hline $\begin{array}{c}\text { Interference } \\
\text { with wearing } \\
\text { glasses/goggles/ } \\
\text { contacts }\end{array}$ & 1 & 2 & $\mathrm{~N} / \mathrm{A}$ & 1 & 1 & 2 & 2 & $\mathrm{~N} / \mathrm{A}$ \\
\hline $\begin{array}{l}\text { Clear line of } \\
\text { vision }\end{array}$ & 3 & 3 & 3 & 5 & 4 & 3 & 3 & 2 \\
\hline $\begin{array}{l}\text { Difficulty of } \\
\text { putting on }\end{array}$ & 3 & 3 & 3 & 4 & 5 & 2 & 2 & 3 \\
\hline $\begin{array}{l}\text { Difficulty to } \\
\text { operate }\end{array}$ & 3 & 3 & 2 & 4 & 2 & 2 & 1 & 1 \\
\hline $\begin{array}{l}\text { Mechanical } \\
\text { interference } \\
\text { with duties }\end{array}$ & 3 & 2 & 2 & 3 & 2 & 3 & 1 & 1 \\
\hline Exertion & 12 & 12 & 9 & 10 & 8 & 7 & 8 & 6 \\
\hline $\begin{array}{l}\text { How many hours } \\
\text { could you wear } \\
\text { this respirator } \\
\text { continuously? }\end{array}$ & 1 & 2 & 3 & 1 & 2 & 3 & 4 & 1 \\
\hline $\begin{array}{l}\text { Perceived } \\
\text { efficiency } \\
\text { against } \\
\text { biological } \\
\text { hazards }\end{array}$ & 3 & 4 & 5 & 5 & 5 & 3 & 3 & 3 \\
\hline $\begin{array}{c}\text { Overall } \\
\text { assessment }\end{array}$ & 2 & 3 & 3 & 3 & 3 & 3 & 2 & 1 \\
\hline
\end{tabular}




\begin{tabular}{|c|c|c|c|c|c|c|c|c|}
\hline Versaflo & $\begin{array}{l}\text { Subject } \\
001\end{array}$ & $\begin{array}{l}\text { Subject } \\
002\end{array}$ & $\begin{array}{l}\text { Subject } \\
003\end{array}$ & $\begin{array}{l}\text { Subject } \\
004\end{array}$ & $\begin{array}{l}\text { Subject } \\
005\end{array}$ & $\begin{array}{l}\text { Subject } \\
006\end{array}$ & $\begin{array}{l}\text { Subject } \\
007\end{array}$ & $\begin{array}{l}\text { Subject } \\
008\end{array}$ \\
\hline General comfort & 2 & 1 & 2 & 3 & 1 & 3 & 4 & 5 \\
\hline $\begin{array}{l}\text { Inspiratory/expir } \\
\text { atory effort }\end{array}$ & 4 & 5 & 4 & 2 & 2 & 2 & 2 & 1 \\
\hline $\begin{array}{l}\text { Overall } \\
\text { breathing } \\
\text { discomfort }\end{array}$ & 3 & 4 & 4 & 2 & 5 & 1 & 2 & 1 \\
\hline $\begin{array}{c}\text { Facial and body } \\
\text { heat }\end{array}$ & 1 & 5 & 5 & 2 & 5 & 2 & 3 & 1 \\
\hline $\begin{array}{l}\text { Overall thermal } \\
\text { comfort }\end{array}$ & 3 & 7 & 8 & 5 & 8 & 5 & 6 & 2 \\
\hline Pressure or pain & 5 & 1 & 2 & 1 & 3 & 3 & 2 & 1 \\
\hline Eye discomfort & 1 & 1 & 3 & 1 & 3 & 2 & 2 & 1 \\
\hline $\begin{array}{c}\text { Interference } \\
\text { with wearing } \\
\text { glasses/goggles/ } \\
\text { contacts }\end{array}$ & 1 & 4 & $\mathrm{~N} / \mathrm{A}$ & 1 & 2 & 2 & 3 & $\mathrm{~N} / \mathrm{A}$ \\
\hline $\begin{array}{c}\text { Clear line of } \\
\text { vision }\end{array}$ & 3 & 3 & 2 & 4 & 4 & 3 & 4 & 4 \\
\hline $\begin{array}{c}\text { Difficulty of } \\
\text { putting on }\end{array}$ & 5 & 3 & 4 & 4 & 3 & 3 & 2 & 1 \\
\hline $\begin{array}{l}\text { Difficulty to } \\
\text { operate }\end{array}$ & 5 & 4 & 3 & 4 & 5 & 3 & 2 & 1 \\
\hline $\begin{array}{c}\text { Mechanical } \\
\text { interference } \\
\text { with duties }\end{array}$ & 5 & 4 & 4 & 3 & 5 & 3 & 2 & 2 \\
\hline Exertion & 17 & 12 & 10 & 8 & 17 & 8 & 9 & 6 \\
\hline $\begin{array}{l}\text { How many hours } \\
\text { could you wear } \\
\text { this respirator } \\
\text { continuously? }\end{array}$ & 1 & 1 & 2 & 2 & 0.25 & 2 & 3 & 2 \\
\hline $\begin{array}{l}\text { Perceived } \\
\text { efficiency } \\
\text { against } \\
\text { biological } \\
\text { hazards }\end{array}$ & 3 & 3 & 5 & 6 & 3 & 3 & 3 & 3 \\
\hline $\begin{array}{c}\text { Overall } \\
\text { assessment }\end{array}$ & 5 & 5 & 5 & 3 & 5 & 3 & 2 & 1 \\
\hline
\end{tabular}




\section{C.2 Vitals}

MAX AIR (PAPR)

Before

\begin{tabular}{|l|l|l|l|r|r|r|r|r|}
\hline & $\begin{array}{l}\text { Subject } \\
\mathbf{0 0 1}\end{array}$ & $\begin{array}{l}\text { Subject } \\
\mathbf{0 0 2}\end{array}$ & $\begin{array}{l}\text { Subject } \\
\mathbf{0 0 3}\end{array}$ & $\begin{array}{l}\text { Subject } \\
\mathbf{0 0 4}\end{array}$ & $\begin{array}{l}\text { Subject } \\
\mathbf{0 0 5}\end{array}$ & $\begin{array}{l}\text { Subject } \\
\mathbf{0 0 6}\end{array}$ & $\begin{array}{l}\text { Subject } \\
\mathbf{0 0 7}\end{array}$ & $\begin{array}{l}\text { Subject } \\
\mathbf{0 0 8}\end{array}$ \\
\hline $\begin{array}{l}\text { Heart Rate } \\
\text { (/mins) }\end{array}$ & N/A & 73 & 76 & 108 & 89 & 70 & 103 & 75 \\
\hline $\begin{array}{l}\text { Respiratory Rate } \\
\text { (/mins) }\end{array}$ & N/A & 12 & 18 & 16 & 18 & 20 & 16 & 16 \\
\hline Sp02 (\%) & N/A & 97 & 98 & 98 & 98 & 98 & 98 & 98 \\
\hline
\end{tabular}

After

\begin{tabular}{|l|r|r|r|r|r|r|r|r|}
\hline & $\begin{array}{l}\text { Subject } \\
\mathbf{0 0 1}\end{array}$ & $\begin{array}{l}\text { Subject } \\
\mathbf{0 0 2}\end{array}$ & $\begin{array}{l}\text { Subject } \\
\mathbf{0 0 3}\end{array}$ & $\begin{array}{l}\text { Subject } \\
\mathbf{0 0 4}\end{array}$ & $\begin{array}{l}\text { Subject } \\
\mathbf{0 0 5}\end{array}$ & $\begin{array}{l}\text { Subject } \\
\mathbf{0 0 6}\end{array}$ & $\begin{array}{l}\text { Subject } \\
\mathbf{0 0 7}\end{array}$ & $\begin{array}{l}\text { Subject } \\
\mathbf{0 0 8}\end{array}$ \\
\hline $\begin{array}{l}\text { Heart Rate } \\
\text { (/mins) }\end{array}$ & 71 & 79 & 82 & 117 & 92 & 77 & 107 & 79 \\
\hline $\begin{array}{l}\text { Respiratory Rate } \\
\text { (/mins) }\end{array}$ & 12 & 12 & 20 & 20 & 16 & 22 & 16 & 18 \\
\hline Sp02 (\%) & 97 & 97 & 98 & 98 & 98 & 97 & 98 & 98 \\
\hline
\end{tabular}

\section{AIR MATE}

(PAPR)

Before

\begin{tabular}{|l|r|l|l|r|r|r|r|r|}
\hline & $\begin{array}{l}\text { Subject } \\
\mathbf{0 0 1}\end{array}$ & $\begin{array}{l}\text { Subject } \\
\mathbf{0 0 2}\end{array}$ & $\begin{array}{l}\text { Subject } \\
\mathbf{0 0 3}\end{array}$ & $\begin{array}{l}\text { Subject } \\
\mathbf{0 0 4}\end{array}$ & $\begin{array}{l}\text { Subject } \\
\mathbf{0 0 5}\end{array}$ & $\begin{array}{l}\text { Subject } \\
\mathbf{0 0 6}\end{array}$ & $\begin{array}{l}\text { Subject } \\
\mathbf{0 0 7}\end{array}$ & $\begin{array}{l}\text { Subject } \\
\mathbf{0 0 8}\end{array}$ \\
\hline $\begin{array}{l}\text { Heart Rate } \\
\text { (/mins) }\end{array}$ & 83 & $\mathbf{7 7}$ & $\mathbf{7 9}$ & 100 & 95 & 64 & 96 & $\mathbf{7 7}$ \\
\hline $\begin{array}{l}\text { Respiratory Rate } \\
\text { (/mins) }\end{array}$ & 14 & 14 & 18 & 17 & 18 & 20 & 16 & 24 \\
\hline Sp02 (\%) & 97 & 97 & 98 & 99 & 98 & 99 & 99 & 98 \\
\hline
\end{tabular}

After

\begin{tabular}{|l|r|r|r|r|r|r|r|r|}
\hline & $\begin{array}{l}\text { Subject } \\
\text { 001 }\end{array}$ & $\begin{array}{l}\text { Subject } \\
\mathbf{0 0 2}\end{array}$ & $\begin{array}{l}\text { Subject } \\
\mathbf{0 0 3}\end{array}$ & $\begin{array}{l}\text { Subject } \\
\mathbf{0 0 4}\end{array}$ & $\begin{array}{l}\text { Subject } \\
\mathbf{0 0 5}\end{array}$ & $\begin{array}{l}\text { Subject } \\
\mathbf{0 0 6}\end{array}$ & $\begin{array}{l}\text { Subject } \\
\mathbf{0 0 7}\end{array}$ & $\begin{array}{l}\text { Subject } \\
\mathbf{0 0 8}\end{array}$ \\
\hline $\begin{array}{l}\text { Heart Rate } \\
\text { (/mins) }\end{array}$ & 87 & $\mathbf{7 4}$ & 89 & 102 & 105 & 71 & 104 & 83 \\
\hline $\begin{array}{l}\text { Respiratory Rate } \\
\text { (/mins) }\end{array}$ & 12 & 14 & 20 & 20 & 16 & 22 & 12 & 24 \\
\hline Sp02 (\%) & 98 & 98 & 97 & 97 & 97 & 99 & 98 & 99 \\
\hline
\end{tabular}


Versflow (PAPR)

Before

\begin{tabular}{|l|r|r|r|r|r|r|r|r|}
\hline & $\begin{array}{l}\text { Subject } \\
\mathbf{0 0 1}\end{array}$ & $\begin{array}{l}\text { Subject } \\
\mathbf{0 0 2}\end{array}$ & $\begin{array}{l}\text { Subject } \\
\mathbf{0 0 3}\end{array}$ & $\begin{array}{l}\text { Subject } \\
\mathbf{0 0 4}\end{array}$ & $\begin{array}{l}\text { Subject } \\
\mathbf{0 0 5}\end{array}$ & $\begin{array}{l}\text { Subject } \\
\mathbf{0 0 6}\end{array}$ & $\begin{array}{l}\text { Subject } \\
\mathbf{0 0 7}\end{array}$ & $\begin{array}{l}\text { Subject } \\
\mathbf{0 0 8}\end{array}$ \\
\hline $\begin{array}{l}\text { Heart Rate } \\
\text { (/mins) }\end{array}$ & 83 & 70 & 76 & 96 & 84 & 69 & 99 & 73 \\
\hline $\begin{array}{l}\text { Respiratory Rate } \\
\text { (/mins) }\end{array}$ & 14 & 13 & 18 & 20 & 20 & 20 & 16 & 20 \\
\hline Sp02 (\%) & 98 & 98 & 98 & 98 & 98 & 97 & 99 & 97 \\
\hline
\end{tabular}

After

\begin{tabular}{|l|r|r|r|r|r|r|r|r|}
\hline & $\begin{array}{l}\text { Subject } \\
\text { 001 }\end{array}$ & $\begin{array}{l}\text { Subject } \\
\mathbf{0 0 2}\end{array}$ & $\begin{array}{l}\text { Subject } \\
\mathbf{0 0 3}\end{array}$ & $\begin{array}{l}\text { Subject } \\
\mathbf{0 0 4}\end{array}$ & $\begin{array}{l}\text { Subject } \\
\mathbf{0 0 5}\end{array}$ & $\begin{array}{l}\text { Subject } \\
\mathbf{0 0 6}\end{array}$ & $\begin{array}{l}\text { Subject } \\
\mathbf{0 0 7}\end{array}$ & $\begin{array}{l}\text { Subject } \\
\mathbf{0 0 8}\end{array}$ \\
\hline $\begin{array}{l}\text { Heart Rate } \\
\text { (/mins) }\end{array}$ & 87 & 75 & 81 & 106 & 105 & 80 & 112 & 80 \\
\hline $\begin{array}{l}\text { Respiratory Rate } \\
\text { (/mins) }\end{array}$ & 15 & 16 & 20 & 18 & 16 & 18 & 20 & 18 \\
\hline Sp02 (\%) & 98 & 98 & 97 & 98 & 98 & 99 & 98 & 99 \\
\hline
\end{tabular}




\section{C.2 Preferences and Acceptability Survey Results}

Evaluation on preference and acceptability comparing low flow rate with high flow rate for low-risk tasks

1. When performing the following tasks (deemed low risks), do you prefer a lower flow rate for the following PAPR?

2. When performing the following tasks (deemed low risks), do you think a lower flow rate is more acceptable?

3. When performing the following tasks (deemed low risks), do you think a lower flow rate is more effective?

\begin{tabular}{|l|l|l|l|l|l|l|l|l|l|}
\hline & $\begin{array}{l}\text { Subject } \\
\mathbf{0 0 1}\end{array}$ & & $\begin{array}{l}\text { Subject } \\
\mathbf{0 0 2}\end{array}$ & & & $\begin{array}{l}\text { Subject } \\
\mathbf{0 0 3}\end{array}$ & & \\
\hline & MAXAIR & $\begin{array}{l}\text { AIR- } \\
\text { MATE }\end{array}$ & Versaflo & MAXAIR & $\begin{array}{l}\text { AIR- } \\
\text { MATE }\end{array}$ & Versaflo & MAXAIR & $\begin{array}{l}\text { AIR- } \\
\text { MATE }\end{array}$ & Versaflo \\
\hline 1. & Yes & Yes & No & Yes & Yes & Yes & No & Yes & Yes \\
\hline 2. & Yes & Yes & No & Yes & Yes & Yes & No & Yes & No \\
\hline 3. & Yes & Yes & No & Yes & Yes & Yes & No & Yes & No \\
\hline
\end{tabular}

\begin{tabular}{|l|l|l|l|l|l|l|l|l|l|}
\hline & $\begin{array}{l}\text { Subject } \\
\mathbf{0 0 4}\end{array}$ & & $\begin{array}{l}\text { Subject } \\
\mathbf{0 0 5}\end{array}$ & & & $\begin{array}{l}\text { Subject } \\
\text { 006 }\end{array}$ & & \\
\hline & MAXAIR & $\begin{array}{l}\text { AIR- } \\
\text { MATE }\end{array}$ & Versaflo & MAXAIR & $\begin{array}{l}\text { AIR- } \\
\text { MATE }\end{array}$ & Versaflo & MAXAIR & $\begin{array}{l}\text { AIR- } \\
\text { MATE }\end{array}$ & Versaflo \\
\hline 1. & No & No & No & No & No & Yes & No & No & No \\
\hline 2. & No & No & No & No & No & Yes & No & No & No \\
\hline 3. & No & No & No & No & No & Yes & No & No & No \\
\hline
\end{tabular}

\begin{tabular}{|l|l|l|l|l|l|l|}
\hline & $\begin{array}{l}\text { Subject } \\
\mathbf{0 0 7}\end{array}$ & & $\begin{array}{l}\text { Subject } \\
\mathbf{0 0 8}\end{array}$ & & \\
\hline MAXAIR & $\begin{array}{l}\text { AIR- } \\
\text { MATE }\end{array}$ & Versaflo & MAXAIR & $\begin{array}{l}\text { AIR- } \\
\text { MATE }\end{array}$ & Versaflo \\
\hline 1. & No & No & No & Yes & Yes & Yes \\
\hline 2. & Yes & Yes & Yes & Yes & Yes & Yes \\
\hline 3. & No & No & No & Yes & Yes & Yes \\
\hline
\end{tabular}

